VILNIAUS GEDIMINO TECHNIKOS UNIVERSITETAS

Edgar Sokolovskij, Jonas Matijošius

\title{
TRANSPORTO PRIEMONIŲ KONSTRUKCINĖS IR EKSPLOATACINĖS MEDŽIAGOS
}

Mokomoji knyga

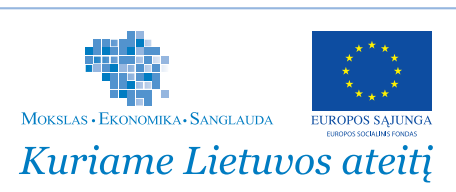

VGTU

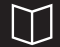

LEIDYKLA

Vilnius TECHNIKA 2012 


\section{E. Sokolovskij, J. Matijošius. Transporto priemonių konstrukcinės}

ir eksploatacinès medžiagos: mokomoji knyga. Vilnius: Technika, 2012, 48 p. [3 aut. 1. 201205 22]

Leidinys skirtas sausumos transporto inžinerijos krypties automobilių transporto, transporto technologinių įrenginių ir geležinkelių transporto specializacijų studentams, studijuojantiems transporto priemonių ir stacionariu variklių degalus, variklių ir kitų agregatų, mechanizmų bei mazgų alyvas ir tepimo medžiagas. Knygoje aprašytos pagrindinès degalų, alyvų ir kitų techninių skysčių savybės ir jas apibūdinantys rodikliai, jų nustatymo priemonès ir metodai.

Mokomoji knyga tinka ir transporto priemonių techninès priežiūros bei remonto specialistams.

Leidinį rekomendavo VGTU Transporto inžinerijos fakulteto studijų komitetas Recenzavo: doc. dr. Gintautas Bureika, Geležinkelių transporto katedra doc. dr. Robertas Pečeliūnas, Automobilių transporto katedra

Leidinys parengtas ir išleistas už Europos struktūrinių fondų lěšas, jomis finansuojant VGTU Transporto inžinerijos, Biomechanikos ir Aviacinès mechanikos inžinerijos projektą „Studijų programų atnaujinimas pagal ES reikalavimus, gerinant studiju kokybę ir taikant inovatyvius studijų metodus" pagal Lietuvos 2007-2013 m. Žmogiškujų išteklių veiksmų programos 2 prioriteto „Mokymasis visą gyvenimą" VP1-2.2-ŠMM-07-K priemonę „Studijų kokybės gerinimas, tarptautiškumo didinimas“. Projekto kodas Nr. VP1-2.2-ŠMM 07-K-01-023, finansavimo ir administravimo sutartis Nr. VP1-2.2-ŠMM-07-K-01-023.

VGTU leidyklos TECHNIKA 1312-S mokomosios metodinès literatūros knyga

http://leidykla.vgtu.lt

Redaktorè Jüratè Balčiūnienè

Maketuotoja Biruté Bilotiené

eISBN 978-609-457-200-5

doi: $10.3846 / 1312-\mathrm{S}$

(Cdgar Sokolovskij, 2012

(C) Jonas Matijošius, 2012

(C) VGTU leidykla TECHNIKA, 2012 


\section{TURINYS}

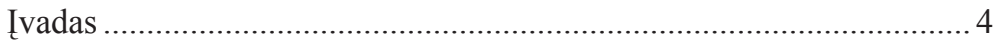

1. Kuras ir techniniai skysčiai ......................................................... 5

2. Skysčio tankis ir jo nustatymas ....................................................... 14

3. Naftos produktų kinematinė klampa ir jos nustatymas ................... 18

4. Naftos produktų pliūpsnio temperatūra ir jos nustatymas ............... 25

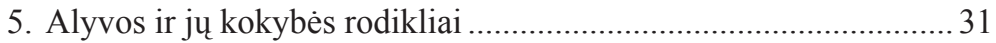

6. Dviejų skysčio komponentų mišinio paruošimas.

Degalų oktaninio ir cetaninio skaičių apskaičiavimas.......................36

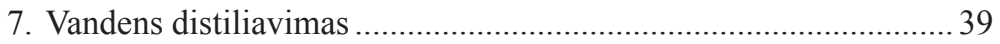

8. Naftos produktų rūgštingumas ir šarmingumas. Jų nustatymas...... 42

9. Aušinimo skysčio užšalimo temperatūra ir elektrolito tankis .........45

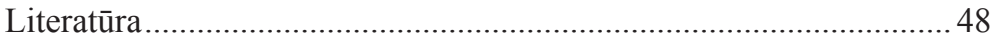




\section{IVADAS}

Taupant energetinius išteklius vis aktualesnis tampa transporto priemonių konstrukcinių ir eksploatacinių medžiagų racionalus naudojimas. Tačiau norint optimizuoti šių medžiagų naudojimą, t. y. mažinti jų sąnaudas ir didinti panaudojimo efektyvumą, būtinos žinios apie šių medžiagų savybes, ịvairius procesus, vykstančius mechanizmuose (tepimo, degimo, aušinimo ir kt. procesus). Nepriekaištingą šiuolaikinių mašinų ir transporto priemonių veikimą galima užtikrinti tik kompleksinèmis priemonèmis, kurias sudaro modernūs konstrukciniai sprendimai jas projektuojant, kokybiškų ir tinkamų eksploatacinių ir konstrukcinių medžiagų naudojimas bei laiku ir kokybiškai atlikta techninė priežiūra. Kiekviena šios sistemos grandis yra svarbi. Net ir turint tobulas transporto priemones, bet naudojant nekokybiškas eksploatacines medžiagas (degalus, tepalus ir kt.) arba tinkamai neprižiūrint technikos, negalima užtikrinti ilgalaikio ir patikimo transporto priemonių darbo.

Ši mokomoji knyga skirta studentams, studijuojantiems transporto priemonių konstrukcines ir eksploatacines medžiagas. Praktinės užduotys, laboratoriniai darbai, susiję su ivvairių techninių skysčių kokybės rodiklių nustatymu, leidžia geriau ịsisavinti teorinị kursą, kurio didžiają dali sudaro žinios apie degalus, tepimo medžiagas ir kitus eksploatacinius skysčius. Jų metu studentai supažindinami su degalų, tepimo medžiagų ir kitų eksploatacinių skysčių savybėmis, jų kokybę apibūdinančiais rodikliais, žymèjimu. Atlikdami laboratorinius darbus ir praktines užduotis, studentai turi galimybę ne tik pamatyti, bet ir išmokti naudotis specialiais prietaisais ir ịanga, skirtais eksploatacinių medžiagu pagrindiniams kokybės rodikliams nustatyti. Išklausę teorinį kursą apie transporto priemonių konstrukcines ir eksploatacines medžiagas ir atlikę laboratorinius darbus, studentai turi ne tik turèti teorinių žinių, bet ir igyti praktinių igūdžių apie šių medžiagu kokybę, ją apibūdinančius rodiklius, jų nustatymo metodus ir ịangą, teisingo naudojimo sąlygas, saugumo reikalavimus dirbant su eksploataciniais skysčiais.

Mokomosios knygos įvadą ir 1-6 skyrius parengė doc. dr. Edgar Sokolovskij, 7-9 skyrius - mgr. Jonas Matijošius. 


\section{KURAS IR TECHNINIAI SKYSČIAI}

Rengiant ši skyrių, panaudoti literatūros šaltiniai (Baczewski, Kałdoński 2008; Baczewski, Kałdoński 2005; Baltènas et al. 1998; Bureika et al. 2008; Jučas 1992; Matijošius, Sokolovskij 2009; Speight 2008; Мартынюк et al. 1993; Стуканов 2003).

Kuras naudojamas šiluminei energijai gauti. Kuru vadinamos medžiagos, kurios lengvai užsidega, degdamos išskiria daug šilumos, yra kaitrios, paplitusios gamtoje ir lengvai gaunamos, patvarios ir pigios, degdamos nekenkia žmogui ir aplinkai. Kuras gali būti dujinis, skystasis ir kietasis. Lengviausiai dega dujinis kuras, nes jo molekulès lengvai maišosi su oru ir greičiau gali susijungti su jame esančiu deguonimi. Degant kietajam kurui, dalis šilumos sunaudojama jam suskaidyti, o degant skystajam kurui - ji išgarinti.

Vidaus degimo varikliuose naudojamas kuras vadinamas degalais. Skystus degalus sudeginti galima tik juos išgarinus. Siekiant, kad degalai kuo geriau sudegtu, stengiamasi juos kuo geriau išpurkšti. Degalu garų ir oro mišinys, naudojamas vidaus degimo varikliuose, vadinamas degiuoju mišiniu.

Vidaus degimo varikliuose degalų cheminè energija paverčiama šilumine, o šiluma - mechaniniu darbu.

Naftos produktai iš naftos pagal išgarinimo temperatūros didejjimą išsidistiliuoja tokiu eiliškumu: dujos, benzinas, žibalas, gazolis (dyzelinas), mazutas (iš kurio vẻliau vakuume išdistiliuojamos alyvos). Išdistiliavus iš mazuto alyvas, lieka gudronas, iš kurio gaunami bitumas ir asfaltinès medžiagos kelių dangoms tiesti.

Kaip degalai dažniausiai yra naudojami benzinas, dyzelinas, žibalas.

\section{Benzinas}

Benzinas būna automobilinis ir aviacinis. Jis naudojamas atitinkamai automobilių ir lèktuvų benzininiuose varikliuose.

Benzinas sudarytas iš angliavandenilių, turinčių nuo 6 iki 11 anglies $\left(\mathrm{C}_{6-11}\right)$ atomų. Benzino tankis $\rho=710-780 \mathrm{~kg} / \mathrm{m}^{3}$, šilumingumas 
$\mathrm{Q} \cong 44-45 \mathrm{MJ} / \mathrm{kg}$, klampa $v_{20}=0,5-0,7 \mathrm{cSt}\left(\mathrm{mm}^{2} / \mathrm{s}\right)$, išgarinimo temperatūra - 35-195 ${ }^{\circ} \mathrm{C}$.

Vienas iš pagrindinių benzino rodiklių yra oktaninis skaičius (OS). Oktaninis skaičius parodo benzino atsparumą detonacijai (išankstiniam savaiminiam užsidegimui). Labai svarbu, kad benzinas variklyje užsidegtų nuo žvakių kibirkšties, t. y. tam tikru momentu, o ne savaime. Todèl benzinas turi būti kuo atsparesnis savaiminiam užsiliepsnojimui variklio cilindre.

Oktaninis skaičius nustatomas, lyginant tiriamaji benziną su etaloniniais degalais, kurie ruošiami iš izooktano $\mathrm{C}_{8} \mathrm{H}_{18}$ ir heptano $\mathrm{C}_{7} \mathrm{H}_{16}$. Izooktanas yra labai atsparus detonacijai ir jo oktaninis skaičius lygus 100, o heptano atsparumas detonacijai lygus 0. Sumaišant šiuos komponentus ivvairiais santykiais, mišinio atsparumą detonacijai galima keisti nuo 0 iki 100. Nustatant oktanini skaičiuc, bandymai atliekami specialiame vieno cilindro variklyje, kurio suslėgimo laipsni galima keisti. Pradžioje naudojamas tiriamasis benzinas, kurio oktaninį skaičių reikia nustatyti. Variklio suslègimo laipsnis didinamas, kol variklis ima detonuoti. Detonaciją registruoja specialūs prietaisai. Po to, nekeičiant suslègimo laipsnio, vietoj benzino į varikli tiekiami etaloniniai degalai. Jų sudètis parenkama taip, kad detonacijos intensyvumas būtų lygiai toks pat, kaip ir tiriamojo benzino. Izooktano tūris procentais etaloniniuose degaluose ir yra benzino oktaninis skaičius. Pavyzdžiui, jeigu benzino mišinys su oru detonuoja lygiai taip pat, kaip naudojant etalonini mišini, susidedantị iš $95 \%$ izooktano ir $5 \%$ heptano, tai benzino oktaninis skaičius yra 95. Oktaninis skaičius nustatomas varikliniu ir tiriamuoju metodais. Abiem atvejais bandymai atliekami tuo pačiu varikliu, tik kiek skiriasi sąlygos (alkūninio veleno sūkiai, uždegimo momentas, mišinio temperatūra). Oktaninis skaičius nustatytas varikliniu metodu (OSV) yra kiek mažesnis, nes nustatomas sunkesnėmis sąlygomis, o oktaninis skaičius nustatytas tiriamuoju metodu (OST) yra šiek tiek didesnis, nes nustatomas lengvesnèmis sąlygomis. Dažniausiai nurodomas oktaninis skaičius nustatytas tiriamuoju metodu (OST).

Kaip jau buvo minèta, detonacija - tai savaiminis, išankstinis mišinio sprogimas. Tai ịvyksta, kai angliavandeniliai oksiduojasi ir 
užsidega anksčiau, negu juos pasiekia degimo zona. Mišinio degimo greitis tuomet yra apie $1500-2500 \mathrm{~m} / \mathrm{s}$, o normalaus degimo atveju jis yra apie $30-40 \mathrm{~m} / \mathrm{s}$. Paprastai mišinys detonuoja degimo pabaigoje, kai susidaro labai nestabilūs ir lengvai sprogstantys deguoniniai junginiai - oksidai ir peroksidai. Detonuojant susidaro smūginès bangos, kurios, sklisdamos dideliu greičiu, atsimuša i cilindro sieneles, sukelia jų virpejjimą. Paprastai detonuoja tik keli procentai vẻliausiai sudegančio mišinio. Detonacija labai žalinga varikliui, sumažèja jo galia ir ekonomiškumas, variklis kaista, labiau dyla. Detonacija būna tuo didesnè, kuo didesnis variklio suslègimo laipsnis, kuo didesnè apkrova, didesnè temperatūra ir slègis, kuo mažesnis benzino oktaninis skaičius. Kitas nenormalaus degimo atvejis yra kaitrinis degimas, nuo kurio ikaista variklio detalès.

Paprastai benzinas gaminamas naudojant mažo oktaninio skaičiaus bazini benziną ir pridedant i ji didelio oktaninio skaičiaus komponentus bei priedus. Oktaninị skaičių galima pakelti:

1. Taikant benzino gamyboje šiuolaikines technologijas ir cheminius perdirbimo būdus, tokius kaip riformingas, izomerizacija ir kt.;

2. Idedant didelio oktaninio skaičiaus komponentus, tokius kaip izooktanas, metiltretbutilo eteris (MTBE), etiltretbutilo eteris (ETBE) ir kt.;

3. Naudojant specialius priedus (cheminius junginius).

Automobilių varikliams paprastai naudojami benzinai, kuriu oktaninis skaičius nustatytas tiriamuoju metodu (OST) yra 92, 95, 98, o aviaciniu benzinų oktaninis skaičius dar didesnis. Kuo didesnis variklio suslègimo laipsnis ir kuo didesnè apkrova, tuo geresniu antidetonacinių savybų, t. y. aukštesnio oktaninio skaičiaus, benziną reikia naudoti.

\section{Dyzelinas}

Dyzelinas naudojamas dyzeliniuose varikliuose.

Dyzelinas sudarytas iš angliavandenilių, turinčių nuo 12 iki 17 anglies $\left(\mathrm{C}_{12-17}\right)$ atomų. Dyzelino tankis $\rho=820-860 \mathrm{~kg} / \mathrm{m}^{3}$, šilumin- 
gumas $Q \cong 43 \mathrm{MJ} / \mathrm{kg}$, klampa $v_{20}=1,5-6 \mathrm{cSt}\left(\mathrm{mm}^{2} / \mathrm{s}\right)$, išgarinimo temperatūra $-160-380{ }^{\circ} \mathrm{C}$.

Vienas iš pagrindinių dyzelino rodiklių yra cetaninis skaičius (CS). Cetaninis skaičius parodo dyzelino užsidegamumą. Dyzeliniuose varikliuose ipurkšti į cilindrą degalai turi patys užsiliepsnoti. Kuo greičiau jie užsidega, tuo lengviau paleisti varikli, jis tyliau veikia ir mažiau dyla.

Cetaninis skaičius nustatomas, lyginant dyzeliną su etaloniniais degalais, kurie ruošiami iš cetano $\mathrm{C}_{16} \mathrm{H}_{34}$ ir $\alpha$-metilnaftalino $\mathrm{C}_{11} \mathrm{H}_{10}$. Cetanas labai lengvai užsidega ir jo cetaninis skaičius lygus 100, o $\alpha$-metilnaftalinas užsidega labai sunkiai ir jo užsidegamumas lygus 0 . Sumaišant šiuos komponentus ịvairiais santykiais, mišinio užsidegamumą galima keisti nuo 0 iki 100. Nustatant cetaninị skaičiu, bandymai atliekami specialiame vieno cilindro dyzeliniame variklyje, kurio suslėgimo laipsni galima keisti. Pradžioje naudojamas tiriamasis dyzelinas, kurio cetanini skaičių reikia nustatyti, ir nustatomas jo degimo indukcijos periodas. Po to, nekeičiant variklio nustatymų, vietoj dyzelino í variklị tiekiami etaloniniai degalai. Jų sudètis parenkama taip, kad indukcijos periodas būtų lygiai toks pat, kaip ir tiriamojo dyzelino. Cetano tūris procentais etaloniniuose degaluose ir yra dyzelino cetaninis skaičius. Pavyzdžiui, jeigu dyzelino užsidegamumas lygiai toks pat kaip ir etaloninio mišinio, susidedančio iš $55 \%$ cetano ir $45 \%$ a-metilnaftalino, tai dyzelino cetaninis skaičius yra 55 .

\section{Žibalas}

Žibalas naudojamas kaip degalai aviaciniuose ir kt. reaktyviniuose varikliuose, žibalo frakcijos gali būti naudojamos gaminant žieminiu rūšių dyzeliną, siekiant palengvinti frakcinę jo sudètį. Taip pat žibalas gali būti naudojamas techninèms reikmėms.

\section{Dujiniai degalai}

Dujiniai degalai dažniausiai naudojami kaip degalai benzininiuose varikliuose, nes jie turi didelị oktanini skaičių. Dažniausiai naudojamos suskystintos naftinès dujos (SND; angl. LPG - liquefied 
petroleum gas), sudarytos iš propano $\mathrm{C}_{3} \mathrm{H}_{8}$ ir butano $\mathrm{C}_{4} \mathrm{H}_{10}$, taip pat suslegtos gamtinès dujos (SGD; angl. CNG - compressed natural gas), kurių pagrindinis komponentas - metanas $\mathrm{CH}_{4}$.

\section{Alyvos ir mazutas}

Iš mazuto distiliuojant vakuume gaminamos alyvos. Liekanagudronas naudojamas gaminant bitumą ir asfaltines medžiagas, naudojamas kelių dangoms tiesti. Alyvos būna variklinės, transmisinės, hidraulinès ir kt. Transmisinès alyvos paprastai yra gaminamos iš sunkesnių frakcijų, todèl yra didesnès klampos.

\section{Techniniai skysčiai}

Techniniai skysčiai gaminami iš angliavandeniliu, glikoliu, esterių, alkoholiu, glicerino ir kt. cheminių medžiagų. Pagal panaudojimo sritị techniniai skysčiai skirstomi į eksploatacinius ir technologinius. Eksploataciniai skysčiai naudojami eksploatuojant mašinas, o technologiniai skysčiai - jas remontuojant. Eksploataciniai skysčiai būna hidrauliniai, aušinimo, apsauginiai, paleidimo, kosmetiniai, elektrolitai ir kt. Technologiniai skysčiai būna plovimo, tepimo-aušinimo, dažymo.

\section{Tirpikliai ir skiedikliai}

Tirpikliai naudojami medžiagai ištirpinti, o skiedikliai - atskiesti. Tirpikliai kartu yra ir skiedikliai ir gali būti naudojami vietoj ju. Tirpikliai būna naftiniai ir nenaftiniai. Naftiniai tirpikliai: vaitspiritas, nefrasas 80/120, nefrasas 155/200 ir kt. Nefraso pavadinimas sudarytas iš žodžių „naftinis tirpiklis“ santrumpų rusų kalba (rus. нефрас = нефтяной растворитель), skaičiai parodo, kokios frakcijos (pagal išgarinimo temperatūras) panaudotos gaminant tirpikli. Naftiniai tirpikliai gali būti benzininiai (pavyzdžiui, nefrasas 80/120, kuri gaminant naudojamos benzino frakcijos), žibaliniai (pavyzdžiui, nefrasas 155/200, kuri gaminant naudojamos žibalo frakcijos). Nenaftiniai tirpikliai gaminami iš nenaftinès kilmès produktu jiems priklauso acetonas ir jo pagrindu pagaminti tirpikliai (pavyzdžiui, tirpiklis 649 ir kt., kur skaičiai 64 rodo, kad tirpdo nitroceliuliozę, kuri įeina į nitroema- 
linių dažų sudèti), rūgštys, šarmai, terpentinas (gaminamas iš medžių saku) ir kt.

Degalu ir techniniu skysčiu kokybès vertinimas pagal išorinius požymius

Pagrindiniai išoriniai požymiai, pagal kuriuos atskiriami degalai ir techniniai skysčiai, yra spalva, kvapas, skaidrumas, mechaninès priemaišos, užterštumas vandeniu, garingumas. Patys paprasčiausi būdai bendrai ịvertinti degalų ir techninių skysčių kokybę yra garinimas ant popieriaus ir deginimas ant stiklo. Tik ką pagamintuose degaluose nebūna nei vandens, nei mechaninių priemaišų. Jie patenka i degalus juos transportuojant, laikant ir naudojant. Degalai šviesoje turi būti skaidrūs ir švarūs, nei ant dugno, nei visame tūryje neturi būti jokių pašalinių kietų ar dervingų dalelių. Vandens neturintys degalai yra visiškai skaidrūs ir stiklinio indelio dugne nebūna jo nuosèdų, o degalai, kuriuose vandens yra daugiau, negu gali ištirpti, būna drumsti. Normaliomis sąlygomis vandens tirpumas naftos produktuose sudaro šimtąsias procento dalis, toks jo kiekis yra nekenksmingas ir nepakeičia degalų skaidrumo. Didesni, negu gali ištirpti, vandens kiekiai susikaupia rezervuarų dugne arba sudaro emulsijas su degalais. Degalų spalva priklauso nuo juose ištirpusių dervų kiekių. Dervos susidaro oksiduojantis degalams ir, kol ištirpsta degaluose, juos nudažo, o kai ju kiekis yra didesnis, negu gali ištirpti, - susidaro nuosėdos. Kokybiškesni šviesesni degalai, nes juose mažiau dervų. Dyzelinui spalvą gali suteikti taip pat sieros junginiai, nors dabar gaminamame dyzeline sieros junginių kiekis yra labai mažas ir griežtai ribojamas. Degalų ir techninių skysčiu spalva ir skaidrumas įvertinami, ipilant i skaidraus stiklo cilindro formos (vienodo skersmens) indelius (kolbas). Benzinas pasižymi stipriu specifiniu kvapu. Dyzelino kvapas nèra stiprus, jis būdingas ir kitiems, išskyrus žibalą ir benziną, naftos produktams.

Pagal garinimą ant popieriaus galima bendrai spręsti apie frakcinę naftos produktų sudètí. Ant balto popieriaus užlašinama po vieną lašą degalų ir techninių skysčiu ir stebima, kaip jis garuoja. Fiksuojama 
išgaravimo trukmè. Kadangi benzinas, lyginant su kitais naftos produktais, sudarytas iš lengvesnių frakcijų, todèl jis išgaruoja greičiau, maždaug per 1 min. Naftos produktai, sudaryti iš sunkesnių frakcijų, garuoja ilgiau, todèl žibalo išgarinimo laikas bus ilgesnis nei benzino, o dyzelino dar daug ilgesnis. Iš garavimo intensyvumo galima nustatyti, ar i̇ benziną nèra patekę sunkesnès frakcinès sudèties naftos produktu. Taip pat apžiūrima vieta, kur buvo užlašinta naftos produkto. Kuo šviesesnè liko dèmè, tuo švaresnis buvo benzinas ar kitas naftos produktas. Jei produktas yra labai užterštas, kartais gali likti vizualiai matomų mechaninių priemaišų ir pan.

Kitas būdas bendrai spręsti apie naftos produktų sudètį yra deginimas ant stiklo. Pagal tai, pavyzdžiui, galima atskirti paprastą benziną ir dvitakčiam varikliui naudojamą mišini, sudarytą iš benzino ir alyvos. Kadangi dvitakčiame variklyje paprastai nèra atskiros tepimo sistemos, tai $\mathfrak{i}$ benziną imaišomas labai nedidelis kiekis alyvos (paprastai alyvos santykis su benzinu būna 1:20 ar dar mažesnis). Sudeginus tokius degalus, lieka alyvos lašelių, kurie atlieka tepimo funkciją. Sudeginus ant stiklo paprastą benziną, jis visiškai sudega. Deginant dvitakčiam varikliui naudojamą mišini, sudarytą iš benzino ir alyvos, ant stiklo lieka alyvos lašeliai arba žiedai, nes jiems sudegti reikia daug aukštesnès temperatūros ir jie nesudega. Kažkiek dega tik lengviausios alyvos frakcijos, dèl to degant šiam mišiniui išsiskiria daugiau dūmų, nei pirmuoju atveju. Taigi taip galima spręsti ir ar benzinas užsiteršęs sunkesnès frakcinès sudèties naftos produktais.

1.1 pav. pavaizduoti indeliai su nafta ir jos produktais (benzinu, žibalu, dyzelinu, buitiniu kuru, alyva, mazutu, bitumu, gudronu), techniniais skysčiais (tirpikliais, skiedikliais, aušinimo skysčiais ir kt.). Šie produktai skiriasi pagal savybes ir išorinius požymius: spalvą, kvapa, skaidrumą, vizualiai įvertina klampą (lyginant su kitais produktais), užterštumą priemaišomis ir kitais junginiais.

Naftos produktų ir techninių skysčių garai yra nuodingi. 


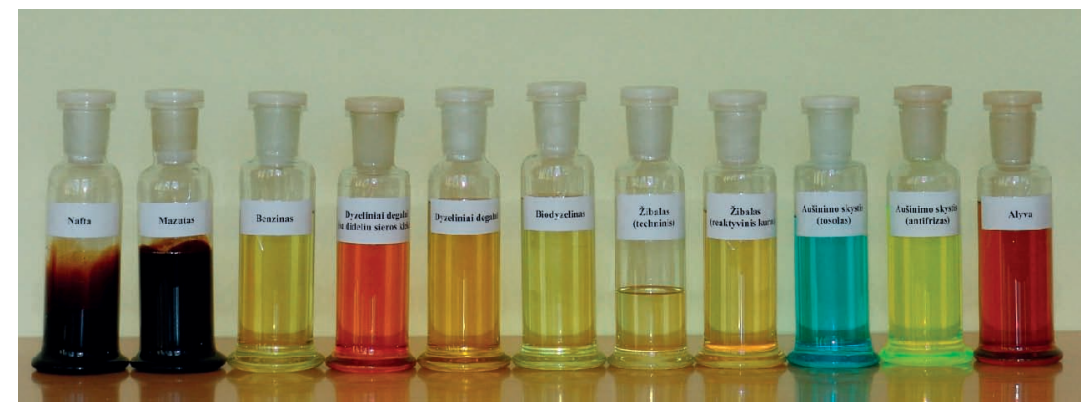

1.1 pav. Nafta, jos produktai ir techniniai skysčiai

Garinant ant popieriaus, nustatomas naftos produktų ir techninių skysčių garingumas, o būtent išgarinimo trukmè. Taip pat įvertinama, ar ties produkto užlašinimo vieta yra kokių nors nešvarumų, priemaišų ir pan.

1.1 lenteleje išvardyti naftos produktai ir techniniai skysčiai bei ju savybès ir išoriniai požymiai.

1.1 lentelè. Naftos produktų ir techninių skysčiu savybès bei išoriniai požymiai

\begin{tabular}{|l|c|c|c|c|c|c|}
\hline $\begin{array}{l}\text { Naftos produk- } \\
\text { tas ar techninis } \\
\text { skystis }\end{array}$ & Spalva & Kvapas & $\begin{array}{c}\text { Skaid- } \\
\text { rumas }\end{array}$ & Klampa & $\begin{array}{c}\text { Užterš- } \\
\text { tumas }\end{array}$ & $\begin{array}{c}\text { Išgari- } \\
\text { nimo } \\
\text { laikas, } \mathrm{s}\end{array}$ \\
\hline Nafta & 2 & 3 & 4 & 5 & 6 & 7 \\
\hline $\begin{array}{l}\text { Benzinas } \\
\text { (šviežias) }\end{array}$ & & & & & & \\
\hline $\begin{array}{l}\text { Benzinas } \\
\text { (senas) }\end{array}$ & & & & & & \\
\hline $\begin{array}{l}\text { Žibalas (reakty- } \\
\text { vinis kuras) }\end{array}$ & & & & & & \\
\hline $\begin{array}{l}\text { Žibalas } \\
\text { (techninis) }\end{array}$ & & & & & & \\
\hline $\begin{array}{l}\text { Dyzelinas } \\
\text { (šviežias) }\end{array}$ & & & & & & \\
\hline $\begin{array}{l}\text { Dyzelinas } \\
\text { (senas) }\end{array}$ & & & & & & \\
\hline
\end{tabular}




\begin{tabular}{|l|l|l|l|l|l|l|}
\hline \multicolumn{1}{|c|}{1} & 2 & 3 & 4 & 5 & 6 & 7 \\
\hline $\begin{array}{l}\text { Dyzelinas } \\
\text { (su dideliu sie- } \\
\text { ros kiekiu) }\end{array}$ & & & & & & \\
\hline Biodyzelinas & & & & & & \\
\hline Buitinis kuras & & & & & & \\
\hline Mazutas & & & & & & \\
\hline $\begin{array}{l}\text { Transmisine } \\
\text { alyva }\end{array}$ & & & & & & \\
\hline Varikline alyva & & & & & & \\
\hline Gudronas & & & & & & \\
\hline Bitumas & & & & & & \\
\hline Vaitspiritas & & & & & & \\
\hline $\begin{array}{l}\text { Nefrasas } \\
80 / 120\end{array}$ & & & & & & \\
\hline Acetonas & & & & & & \\
\hline Tirpiklis 649 & & & & & & \\
\hline Terpentinas & & & & & & \\
\hline $\begin{array}{l}\text { Aušinimo } \\
\text { skystis }\end{array}$ & & & & & & \\
\hline
\end{tabular}




\section{SKYSČIO TANKIS IR JO NUSTATYMAS}

Rengiant ši skyrių, panaudoti literatūros šaltiniai (Baltėnas et al. 1998; Jučas 1992; Matijošius, Sokolovskij 2009; Мартынюк et al. 1993; Стуканов 2003).

Tankis nustatomas dalijant medžiagos masę iš jos tūrio, išmatuoto $20{ }^{\circ} \mathrm{C}$ temperatūroje. Tankio matavimo vienetas (dimensija) SI sistemoje $-\mathrm{kg} / \mathrm{m}^{3}$, taip pat kartais matuojamas $\mathrm{g} / \mathrm{cm}^{3}$. Skysčio tankis nustatomas areometru.

Santykinis tankis yra medžiagos tankio $20^{\circ} \mathrm{C}$ temperatūroje santykis su vandens tankiu $4{ }^{\circ} \mathrm{C}$ temperatūroje. Kadangi vandens tankis $4{ }^{\circ} \mathrm{C}$ temperatūroje yra $1 \mathrm{~g} / \mathrm{cm}^{3}$, tai santykinis tankis skaitine reikšme sutampa su absoliutiniu, tik neturi dimensijos. Santykinis tankis yra žymimas $\rho_{4}{ }^{20}$.

Esant $4{ }^{\circ} \mathrm{C}$ temperatūrai, vandens tankis yra lygus $1000 \mathrm{~kg} / \mathrm{m}^{3}$ arba $1 \mathrm{~g} / \mathrm{cm}^{3}$. Skysčių tankis priklauso nuo temperatūros, jai didèjant tankis mažèja, o temperatūrai mažèjant - tankis didèja. Todèl, nurodant tanki, visada nurodoma temperatūra, kurioje jis buvo nustatytas.

Naftos produktų tankis priklauso ne tik nuo temperatūros, bet ir nuo jų cheminès sudèties. Kadangi vandenilio atominè masè yra daug mažesnè negu anglies, tai tankis yra mažesnis tų angliavandenilių, kurių molekulèse daugiau vandenilio atomų ir mažiau anglies atomų. Tokių angliavandenilių būna žemesnè virimo temperatūra, mažesnè klampa ir didesnis šilumingumas (nes vandenilis šilumingesnis negu anglis).

Iš tankio galima spręsti apie naftos produktų cheminę ir frakcinę sudèti, klampą ir šilumingumą, naftos produkto rūši, užsiteršimą kitos rūšies produktais. Tankiu naudojamasi, kai reikia nustatyti naftos produktų masę, žinant tūrị, ir atvirkščiai. Pagal tanki nustatoma kai kurių techninių skysčių (tokių kaip antifrizas, elektrolitas ir kt.) koncentracija, kartu ir jų tinkamumas naudoti tam tikromis sąlygomis.

Orientaciniai naftos produktų tankiai yra tokie: benzino - 710$780 \mathrm{~kg} / \mathrm{m}^{3}$, žibalo $-790-820 \mathrm{~kg} / \mathrm{m}^{3}$, dyzelino $-820-860 \mathrm{~kg} / \mathrm{m}^{3}$, aly$\operatorname{vos}-900-950 \mathrm{~kg} / \mathrm{m}^{3}$. Ivairioje literatūroje nurodomos skirtingos 
atitinkamų naftos produktų tankiu ribos, nes konkrečiu atveju, gaminant tam tikrus naftos produktus, gali būti naudojamos skirtingos frakcijos, t. y. gaminant naftos produktus skirtingais būdais gali būti gaunami kiek lengvesnès ar sunkesnès frakcinès sudèties produktai.

Tankio priklausomybe nuo temperatūros gali būti išreiškiama tokia formule:

$$
\rho_{t}=\rho_{20}-\gamma(t-20) ;
$$

čia: $\rho_{t}-$ skysčio tankis temperatūroje $t\left({ }^{\circ} \mathrm{C}\right), \mathrm{kg} / \mathrm{m}^{3}$;

$\rho_{20}$ - skysčio tankis temperatūroje $20^{\circ} \mathrm{C}, \mathrm{kg} / \mathrm{m}^{3}$;

$\gamma$ - tankio temperatūrinè pataisa, $\mathrm{kg} /\left(\mathrm{m}^{3} \cdot{ }^{\circ} \mathrm{C}\right)$;

$t$ - temperatūra, kurioje nustatomas tankis, ${ }^{\circ} \mathrm{C}$.

Tankis gali būti nustatomas, esant bet kokiai temperatūrai $t\left({ }^{\circ} \mathrm{C}\right)$, o tada, jei reikia, apskaičiuojamas tankis normaliomis sąlygomis, t. y. esant plius $20^{\circ} \mathrm{C}$ temperatūrai. Tam naudojama tokia formulè:

$$
\rho_{20}=\rho_{t}+\gamma(t-20) .
$$

Analogiškai gali būti nustatomas tankis esant bet kokiai kitai temperatūrai. Pavyzdžiui, degalams kartais pagal standartus nustatomas tankis $15^{\circ} \mathrm{C}$ temperatūroje.

Ivairių skysčių tankiai, norint juos lyginti tarpusavyje, turi būti nustatyti arba perskaičiuoti vienoje temperatūroje, tik tada galima juos lyginti tarpusavyje ir spręsti apie skysčių savybes. Esant kokiai nors kitai temperatūrai perskaičiuoti tankio nereikia, kai norima pagal skysčio tūri nustatyti masę, arba atvirkščiai, esamoje temperatūroje. Tada naudojama tankio reikšmè, nustatyta šioje temperatūroje.

Areometrai (prietaisai skysčio tankiui nustatyti) būna trijų tipų:

1. 4 ženklų po kablelio tikslumu, su termometru;

2. 3 ženklų po kablelio tikslumu, su termometru (žr. 2.1 pav.);

3. 3 ženklų po kablelio tikslumu, be termometro (žr. 2.2 pav.). 


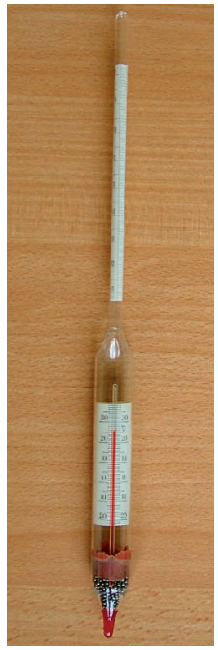

2.1 pav. 2-o tipo areometras

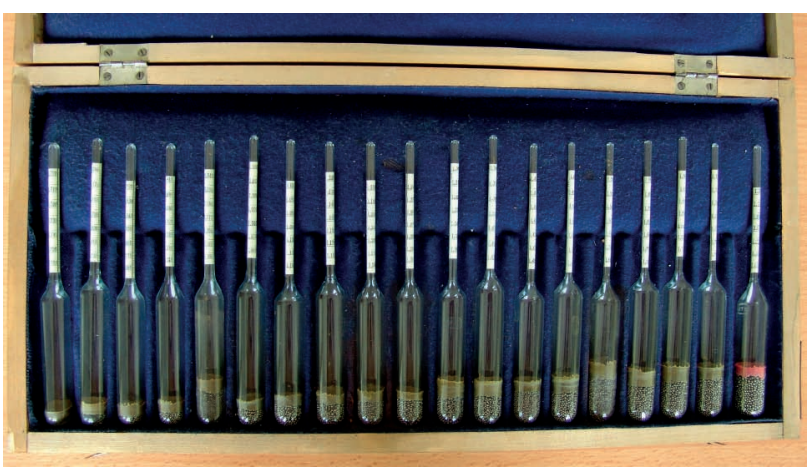

2.2 pav. 3-io tipo areometrų komplektas

Nustatant tanki naftos produktas (benzinas, žibalas, dyzelinas ir kt.), kurio tankis bus nustatomas, ipilamas i skaidraus stiklo cilindro formos kolbą. Išmatuojama skysčio temperatūra. Prieš tai skystis turi kuri laiką pastovèti patalpoje, kurioje bus nustatomas jo tankis, kad nusistovètų jo temperatūra. Iš pradžiu paimamas mažiausiam tankiui matuoti skirtas areometras, nes per dideliam tankiui matuoti skirtas areometras gali nuskęsti. Tai ypač svarbu, kai tankis tiesiogiai matuojamas dideliame rezervuare ar kai skystis sumaišytas su kitokio tankio skysčiu - dèl to negalima iš anksto tiksliai numatyti galimų tankio reikšmių. Tada imamas kitas areometras ir t. t., kol areometras nusileis i skystį tiek, kad skysčio paviršius bus ties areometro tankių reikšmių skale. Kai areometras nustoja svyruoti, pagal skysčio paviršiaus viršutini kraštą nustatomas skysčio tankis esamoje temperatūroje $\rho_{t}$ (žr. 2.3 pav.). Pagal formulę (2.2) apskaičiuojamas tankis normaliomis sąlygomis $\rho_{20}$, t. y. tankis, esant plius $20^{\circ} \mathrm{C}$ temperatūrai. Tankio temperatūrinès pataisos $\gamma$ reikšmės surandamos pagal specialias lenteles. CGS sistemoje $\left(\mathrm{g} / \mathrm{cm}^{3}\right)$ nustatytos tankio reikšmés gali būti perskaičiuojamos i SI sistemą $\left(\mathrm{kg} / \mathrm{m}^{3}\right)$, ir atvirkščiai. 

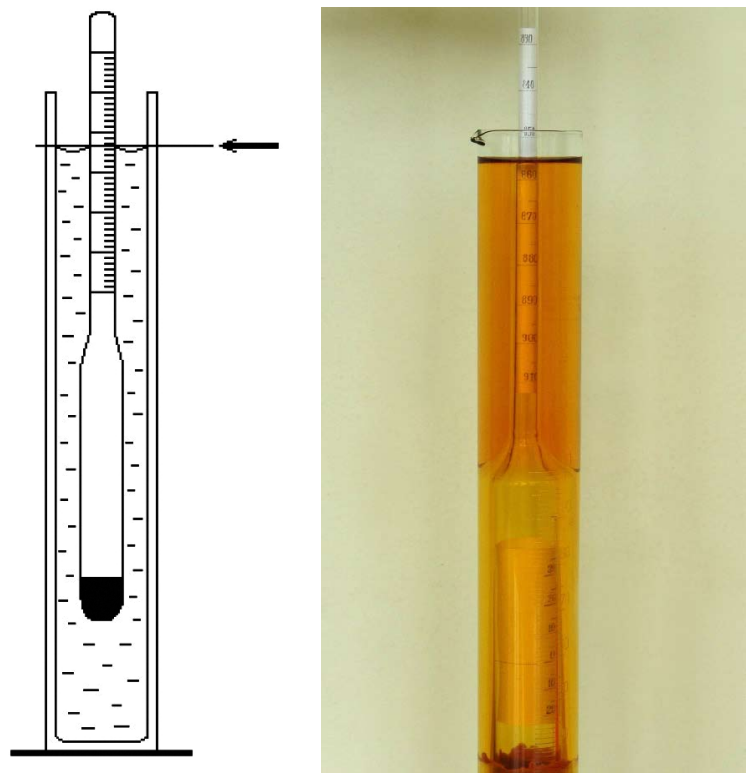

2.3 pav. Skysčio tankio nustatymas areometru 


\section{NAFTOS PRODUKTŲ KINEMATINĖ KLAMPA IR JOS NUSTATYMAS}

Rengiant ši skyrių, panaudoti literatūros šaltiniai (Baltėnas et al. 1998; Jučas 1992; Matijošius, Sokolovskij 2009; Мартынюк et al. 1993; Стуканов 2003).

Klampa - tai rodiklis, ivvertinantis skysčio vidaus trinti. Tai yra vienas iš pagrindinių degalų ir alyvų tekumą apibūdinančių rodiklių. Klampa būna dinaminè, kinematinè ir sąlyginè.

Trinties jègą tarp dviejų paviršių, atskirtų skysčio sluoksniu, galima apskaičiuoti pagal tokią formulę:

$$
F=\eta S v / h \text {; }
$$

čia: $\eta$-dinaminè klampa, $\mathrm{Pa} \cdot \mathrm{s}$;

$S$ - kontaktuojančiu paviršiu plotas, $\mathrm{m}^{2}$;

$v$ - paviršių judèjimo vienas kito atžvilgiu greitis, $\mathrm{m} / \mathrm{s}$;

$h$ - skysčio sluoksnio storis, $\mathrm{m}$.

Dinaminès klampos matavimo vienetas SI sistemoje $-\mathrm{Pa} \cdot \mathrm{s}$. Taip pat naudojamas kitas dinaminès klampos matavimo vienetas $-\mathrm{P}$ (Puazas). Kadangi techninių skysčių klampa paprastai yra daug mažesnè negu $1 \mathrm{~Pa} \cdot s$ ar $1 \mathrm{P}$, tai dažniausiai naudojami mažesni matavimo vienetai: $\mathrm{mPa} \cdot \mathrm{s}\left(1 \mathrm{mPa} \cdot \mathrm{s}=10^{-3} \mathrm{~Pa} \cdot \mathrm{s}\right)$ arba $\mathrm{cP}\left(1 \mathrm{cP}=10^{-2} \mathrm{P}\right)$. Norint perskaičiuoti vienus matavimo vienetus i kitus, vadovaujamasi tokiu jų ryšiu: $1 \mathrm{cP}=1 \mathrm{mPa} \cdot \mathrm{s}$. Dinaminė klampa nustatoma rotaciniu viskozimetru. Jo veikimo principas pagristas skysčio pasipriešinimo nustatymu, atitinkamu dažniu sukant i ji panardintą rotorių.

Praktikoje, pavyzdžiui, degalams, dažniau nustatoma skysčių kinematinè klampa v. Tai santykinis skysčio vidaus trinties koeficientas, kuri galima apskaičiuoti pagal tokią formulę:

$$
v=\eta / \rho
$$

čia: $\rho$ - skysčio tankis, $\mathrm{kg} / \mathrm{m}^{3}$. 
Kinematinès klampos matavimo vienetas SI sistemoje $-\mathrm{m}^{2} / \mathrm{s}$. Taip pat naudojamas kitas kinematinès klampos matavimo vienetas St (Stoksas). Kadangi techniniu skysčiu klampa paprastai yra daug mažesnè negu $1 \mathrm{~m}^{2} / \mathrm{s}$ ar $1 \mathrm{St}$, tai dažniausiai naudojami mažesni matavimo vienetai: $\mathrm{mm}^{2} / \mathrm{s}\left(1 \mathrm{~mm}^{2} / \mathrm{s}=10^{-6} \mathrm{~m}^{2} / \mathrm{s}\right)$ arba $\mathrm{cSt}\left(1 \mathrm{cSt}=10^{-2} \mathrm{St}\right)$. Norint perskaičiuoti vienus matavimo vienetus i kitus, vadovaujamasi tokiu jų ryšiu: $1 \mathrm{cSt}=1 \mathrm{~mm}^{2} / \mathrm{s}$. Kinematinè klampa nustatoma kapiliariniu viskozimetru. Jo veikimo principas pagristas nustatyto kiekio skysčio ištekejjimo per kapiliarą trukmès nustatymu. Nustačius ištekèjimo trukmę, skysčio kinematinę klampą tam tikroje temperatūroje $v_{t}$ [cSt ar mm²/s] galima apskaičiuoti pagal tokią formulę:

$$
\mathrm{v}_{t}=C \cdot \tau \cdot K
$$

čia: $C$ - viskozimetro konstanta, $\mathrm{cSt} / \mathrm{s}\left(\mathrm{mm}^{2} / \mathrm{s}^{2}\right)$;

$\tau$ - skysčio ištekejjimo trukmè, $\mathrm{s}$;

$K$ - koeficientas, ivertinantis skysčio hidrostatinio slègio aukščio pakitimą priklausomai nuo temperatūros.

Koeficientas $K$, ivertinantis skysčio hidrostatinio slègio aukščio pakitimą priklausomai nuo temperatūros, apskaičiuojamas pagal tokią formulę:

$$
K=1+0,00004\left(t_{b}-t_{u}\right) ;
$$

čia: $t_{b}$ - naftos produkto bandymo temperatūra, ${ }^{\circ} \mathrm{C}$;

$t_{u}-$ naftos produkto temperatūra, užpildant viskozimetrą, ${ }^{\circ} \mathrm{C}$.

Matyti, kad nedidelis naftos produkto bandymo temperatūros $t_{b}$ ir jo temperatūros $t_{u}$, užpildant viskozimetra, skirtumas $\left(<10{ }^{\circ} \mathrm{C}\right)$ neturi didelès įtakos klampos skaičiavimui, taigi galima teigti, kad tokiu atveju koeficientas $K=1$. Tokiu atveju formulę (3.3) galima užrašyti taip:

$$
v_{t}=C \cdot \tau .
$$

Koeficiento $K$ reikšmès gali turèti reikšmingą itaką klampos skaičiavimui, kai naftos produkto bandymo temperatūra labai skiriasi nuo 
jo temperatūros, užpildant viskozimetra, pavyzdžiui, kai nustatoma naftos produkto klampa esant plius $100^{\circ} \mathrm{C}$ temperatūrai.

Sąlyginè klampa rodo, kiek kartu naftos produkto klampa, esant bandymo temperatūrai, skiriasi nuo distiliuoto vandens klampos, kurio temperatūra plius $20^{\circ} \mathrm{C}$. Tai $200 \mathrm{~cm}^{3}$ skysčio kurioje nors temperatūroje ir tokio pat distiliuoto vandens kiekio, kurio temperatūra plius $20{ }^{\circ} \mathrm{C}$, ištekejjimo iš viskozimetro laiko santykis.

Skysčių klampa priklauso nuo temperatūros, jai didejjant - klampa mažejja, mažejant - klampa dideja. Taigi nurodant klampa, visada nurodoma temperatūra, kurioje ji buvo nustatyta: $v_{t}, \eta_{t}$ (pavyzdžiui, $v_{40}$ ar $\left.v_{100}\right)$.

Benzinų klampa yra labai nedidelè $\left(v_{20}=0,5-0,7 \mathrm{cSt}\right)$ ir mažai priklauso nuo temperatūros, todèl šis rodiklis benzinams nèra svarbus. Iš tekumo rodiklių benzinams kontroliuojami tik mechaninių priemaišų kiekis ir vandens kiekis.

Dyzelinas yra didesnès klampos nei benzinas, jo klampa labiau priklauso nuo temperatūros. Todèl dyzelinams kontroliuojama daugiau tekumo rodikliu, t. y. ne tik klampa, bet ir drumstimosi temperatūra, ribiné filtravimosi temperatūra, stingimo temperatūra, mechaninių priemaišų kiekis, vandens kiekis, filtravimosi koeficientas.

Dyzelinui paprastai nustatoma kinematinè klampa, nes ji labai svarbi eksploatuojant varikli. Nuo kinematinès klampos priklauso degalu tekumas, tiekimo linijos agregatų išdilimo intensyvumas ir sandarumas, degiojo mišinio paruošimo kokybè. Klampesni degalai geriau tepa ir sandarina sandūras, tačiau sunkiau praeina per valymo filtrus ir blogiau susimaišo su oru, mažesnès klampos degalai - priešingai. Todèl dyzelino klampa turi būti optimali, nes ir per didelè, ir per maža klampa blogina degalų kokybę. Optimali dyzelino klampa $-v_{20}=1,5-6 \mathrm{cSt}\left(\mathrm{mm}^{2} / \mathrm{s}\right)$. Dyzelino klampa priklauso nuo temperatūros, ypač staigiai ji dideja esant neigiamai temperatūrai. Kadangi kuo mažesnè klampa, tuo paprastai ji mažiau priklauso nuo temperatūros, gaminant žieminių rūšiu dyzelina, stengiamasi palengvinti frakcinę jo sudèti. Todèl žieminis dyzelinas paprastai būna mažesnès klampos (apie $1,5-5 \mathrm{cSt}$ ), o vasarinis dyzelinas gali būti kiek klampesnis (3-6 cSt). Žiemą dyzelino tekumą 
gali sutrikdyti ir susidarantys parafino kristalai. Parafinų kristalai susidaro tuo intensyviau, kuo daugiau degaluose yra alkanų grupès angliavandeniliu, kurie normaliomis sąlygomis yra labai pageidaujamas dyzelino komponentas, nes pagerina dyzelino užsidegamuma, kartu ir jo cetanini skaičių. Nukritus temperatūrai, alkanų grupès angliavandeniliai kristalizuojasi, pakeldami stingimo temperatūrą. Siekiant, kad žiemą dyzelinas būtų kuo mažiau linkęs drumstis ir stingti, gaminant žieminių rūšių dyzeliną, atliekama deparafinizacija. Deparafinizacijos tikslas - pašalinti iš naftos produktų kietus angliavandenilius, nes norima pažeminti stingimo temperatūrą. Deparafinizuojant paprastai pašalinami didelès molekulinès masès alkanų grupès angliavandeniliai ir kt. nepageidaujami junginiai. Deparafinizuoti degalus galima ịvairiais būdais. Vienas iš jų - deparafinizuojant kristalizacija. Dyzelinas skiedžiamas tirpikliais, tada atšaldomas iki žemos temperatūros. Skiediniuose kieti angliavandeniliai lengviau kristalizuojasi ir juos nesunku atskirti centrifuga. Deparafinizuotas produktas turi daug žemesnę stingimo temperatūrą nei žaliava ir gali būti naudojamas gaminant žieminių rūšių dyzeliną. Po deparafinizacijos, pašalinus alkanų grupès angliavandenilius, kiek pablogèja dyzelino užsidegamumas, kartu sumažèja jo cetaninis skaičius. Norint padidinti deparafinizuoto dyzelino cetaninį skaičių, i ji dedama specialių priedu - užsidegimo iniciatorių.

Klampa yra taip pat labai svarbus alyvu kokybès rodiklis. Hidraulinių alyvų, kurios dirba ganètinai žemoje temperatūroje, kinematinè klampa paprastai nustatoma plius $40{ }^{\circ} \mathrm{C}$ temperatūroje. Variklinių ir transmisinių alyvų, naudojamų aukštoje temperatūroje, kinematinè klampa paprastai nustatoma plius $100{ }^{\circ} \mathrm{C}$ temperatūroje, nes būtina žinoti ne tik jų klampą normaliomis sąlygomis, bet ir klampą darbinejje temperatūroje.

Variklinėms ir transmisinėms alyvoms, ypač visasezonėms, dažnai nustatoma grafinè klampos priklausomybè nuo temperatūros $v=f(t)$, nes reikia žinoti klampos priklausomybę nuo temperatūros, tai yra kaip kinta klampa, esant aukštai ir žemai temperatūrai.

3.1 pav. pavaizduotas kapiliarinis viskozimetras. Matuojant naftos produktų kinematinę klampą, viskozimetro kapiliaro dydis (jo 
skersmuo) parenkamas taip, kad skystis ištekètú per tam tikrą laiką (paprastai ne ilgiau kaip per 3 min.), kitaip padideja matavimo paklaida. Taigi klampesnių naftos produktų kinematinè klampa matuojama kapiliariniais viskozimetrais su didesnio skersmens kapiliaru, o mažesnès klampos produktų - su mažesnio skersmens kapiliaru. Priklausomai nuo kapiliaro skersmens kiekvienas kapiliarinis viskozimetras turi savo viskozimetro konstantą (paprastai matuojama cSt/s arba $\mathrm{mm}^{2} / \mathrm{s}^{2}$ ), kuri nurodoma jo naudojimo instrukcijoje.

Paprastai nustatoma dyzelino kinematinè klampa, nes tai yra labai svarbus jo kokybès rodiklis. Prieš bandymus viskozimetras turi būti kruopščiai išplautas, panaudojant tam skirtas specialias priemones, ir išdžiovintas džiovinimo spintoje. Naftos produktas prieš bandymą filtruojamas. Termostate nustatoma reikiama temperatūra.
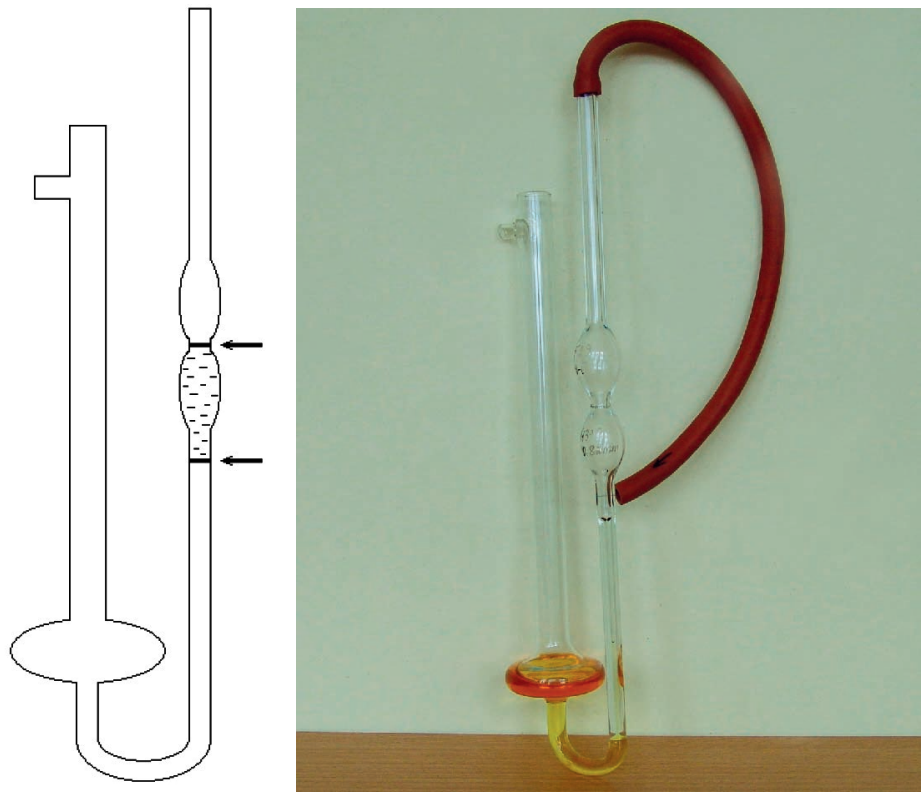

3.1 pav. Kapiliarinis viskozimetras

Kapiliarinis viskozimetras užpildomas naftos produktu pagal specialią metodiką. 
Kapiliarinis viskozimetras užpildomas taip: žarnelè, kuri matuojant klampą būna užmauta ant viskozimetro ilgesnio stiklinio vamzdelio (žr. 3.1 pav.), užmaunama ant trumpesnio jo vamzdelio antgalio. Apvertus viskozimetra, jo ilgesnio stiklinio vamzdelio galas panardinamas i skysti, kuriuo norima užpildyti viskozimetrą. Trumpesnis viskozimetro vamzdelis tuo metu turi būti užkimštas. Sudarant trumpesniame stikliniame vamzdelyje slègi, mažesnį nei ilgesniame vamzdelyje (tai daroma per ant antgalio užmautą žarnelę), skystis pradeda kilti ilgesniu vamzdeliu. Kai skystis pasiekia tam tikrą ribą (ji yra pažymèta brūkšneliu), viskozimetras apverčiamas i normalią padetị. Žarnelè nuo viskozimetro trumpesnio vamzdelio antgalio nuimama ir užmaunama atgal ant viskozimetro ilgesnio vamzdelio (žr. 3.1 pav.). Viskozimetre turi būti tam tikras konkretus skysčio kiekis, jeigu jo yra daugiau ar mažiau, tai padidejja matavimo paklaida. Taip pat reikia stengtis, kad užpildant viskozimetrą i jį nepatektų oro burbuliukų.

Užpildytas kapiliarinis viskozimetras ịstatomas į termostatą vertikaliai, kad visos 3 burbuolès būtu panardintos (žr. 3.2 pav.). Sudarant viskozimetro ilgesniame stikliniame vamzdelyje slègi, mažesnį nei ilgesniame (tai daroma per ant jo uždètą žarnelę), skystis pradeda kilti kapiliaru ir užpildo ilgesniame stikliniame vamzdelyje esančias burbuoles. Naftos produkto turi būti itraukta tiek, kad viršutinè burbuolè būtu užpildyta apie $1 / 3$ jos aukščio. Kol žarnelès galas yra užkimštas, skysčio paviršius lieka tame pačiame aukštyje. Pasiruošus matuoti, žarnelès galas atidaromas ir skystis pradeda bẻgti žemyn. Chronometru arba laikrodžiu užfiksuojamas laikas $\tau$ (sekundèmis), per kurị naftos produktas išteka nuo brūkšnelio, esančio tarp burbuolių, iki brūkšnelio, esančio ant kapiliaro. Kapiliarinis viskozimetras parenkamas taip, kad skystis ištekètu per tam tikrą laiką (paprastai ne ilgiau kaip per $3 \mathrm{~min}$.), jeigu tai trunka ilgiau, padideja matavimo paklaida, todèl parenkamas kitas (didesnio kapiliaro skersmens) viskozimetras.

Bandomo naftos produkto kinematinè klampa apskaičiuojama pagal formulę (3.3). Konkrečiu kapiliarinių viskozimetrų konstantų $C$ reikšmes (cSt $/ \mathrm{s}$ ar $\mathrm{mm}^{2} / \mathrm{s}^{2}$ ) pateikiamos jų techninèje dokumentacijoje. Koeficientas $K$, ivertinantis skysčio hidrostatinio slègio aukščio pakitimą 
priklausomai nuo temperatūros, apskaičiuojamas pagal formulę (3.4). Jeigu naftos produkto bandymo temperatūra tokia pati kaip ir jo užpildymo temperatūra, t. y. $t_{b}=t_{u}$, arba šių temperatūrų yra labai nedidelis skirtumas $\left(<10^{\circ} \mathrm{C}\right)$, tai galima naudotis supaprastinta formule (3.5).

Naftos produktų kinematinè klampa apskaičiuojama 4 reikšmingų skaičių tikslumu.

Apskaičiavus naftos produkto kinematinę klampa, jos reikšmè (cSt, $\mathrm{mm}^{2} / \mathrm{s}$ ) gali būti perskaičiuojama į SI sistemą $\left(\mathrm{m}^{2} / \mathrm{s}\right)$, ir atvirkščiai.

Pagal formulę (3.2) gali būti apskaičiuojama dinaminè klampa $\eta(\eta=v \cdot \rho)$. Prièmus tam tikrą naftos produkto tankio reikšmę (turi būti priimamas to paties naftos produkto tankis esant tai pačiai temperatūrai), gali būti apskaičiuojama dinaminè klampa $\eta$. SI sistemoje gauta dinaminès klampos reikšmė (Pa.s) gali būti pervedama ị $\mathrm{P}$ (arba cP), ir atvirkščiai.

Jeigu nustatoma naftos produkto kinematinè klampa aukštesnėje nei aplinkos temperatūroje, tai temperatūra termostate pakeliama elektros krosnele (žr. 3.3 pav.). Tuomet naftos produkto bandymo temperatūra skirsis nuo jo užpildymo temperatūros ir skaičiuojant kinematinę klampa reikia naudotis formule (3.3). Kai bandymo temperatūra didesné kaip plius $90{ }^{\circ} \mathrm{C}$, termostatas užpildomas ne vandeniu (kuris tokiu atveju gali pradèti virti), o šviesia mineraline alyva.

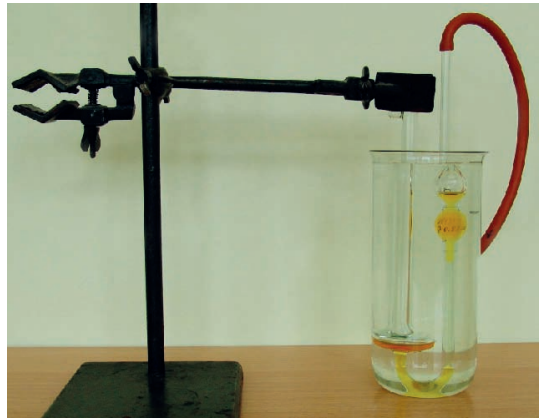

3.2 pav. Naftos produkto kinematinès klampos nustatymas kapiliariniu viskozimetru

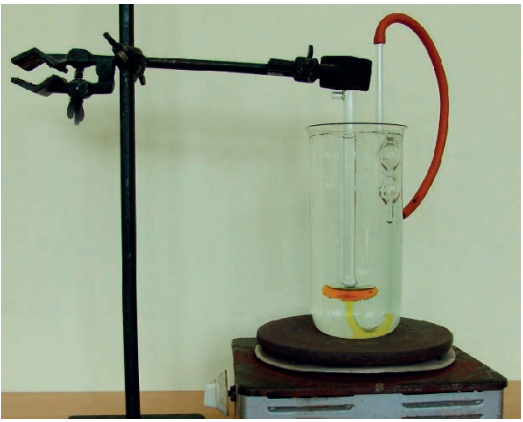

3.3 pav. Naftos produkto kinematinès klampos nustatymas kapiliariniu viskozimetru, pakeliant bandymo temperatūrą elektros krosnele 


\section{NAFTOS PRODUKTŲ PLIŪPSNIO TEMPERATŪRA IR JOS NUSTATYMAS}

Rengiant ši skyrių, panaudoti literatūros šaltiniai (Baltėnas et al. 1998; Jučas 1992; Matijošius, Sokolovskij 2009; Мартынюк et al. 1993; Стуканов 2003).

Degalų degimo procese išskiriamos trys fazès: užsiliepsnojimo, intensyvaus degimo ir baigiamojo degimo. Degimo metu degalų molekulès intensyviai oksiduojasi, t. y. jungiasi su deguonimi. Temperatūrai kylant, oksidacijos reakcijos intensyvèja ir degalai užsiliepsnoja. Užsiliepsnojimas yra pradinè fazè, kurios metu degalai ¡kaista iki temperatūros, reikalingos degimui. Degalams užsiliepsnojus, prasideda intensyvaus degimo fazè, kurios metu sudega pagrindinè masė degalų. Degalų likučiai sudega baigiamojo degimo fazejje. Po intensyvaus dyzelinių degalų degimo fazès dar išskiriama lètojo degimo fazè, kurios metu sudega sunkesnès degalų frakcijos, nespejjusios sudegti intensyvaus degimo fazeje.

Degalų užsiliepsnojimas vertinamas pliūpsnio (plyksnio), užsiliepsnojimo ir savaiminio užsiliepsnojimo temperatūromis. Pliūpsnio (plyksnio) temperatūra - tai tokia žemiausia temperatūra, kuriai esant kaitinamo naftos produkto garai su aplinkos oru sudaro toki mišini, kuris, priartinus prie jo atvirą ugni, plyksteli ir vėl užgęsta. T. y. susidaro pakankamas naftos produkto garų kiekis, kad įvyktų plyksnis, bet nepakankamas, kad produktas nuolat degtų. Liepsna gęsta todèl, kad produkto garavimo greitis yra per mažas. Lengvesnių naftos produktų pliūpsnio temperatūra būna žemesnè, nes greičiau susidaro galinčios užsidegti koncentracijos garų ir oro mišinys. Saugesni yra tie naftos produktai, kurių pliūpsnio temperatūra yra aukštesnè. Užsiliepsnojimo temperatūra - tai tokia žemiausia temperatūra, kurioje naftos produktai, priartinus ugni, užsiliepsnoja ir dega neužgesdami. Tai yra naftos produkto garų kiekis. jau yra pakankamas, kad produktas degtų nuolat Savaiminio užsiliepsnojimo temperatūra - tai tokia žemiausia temperatūra, kurioje naftos produktai užsiliepsnoja savaime. Lengviausiai dega dujiniai degalai, nes jų molekulès lengviausiai maišosi su oro 
ir jungiasi su jame esančiu deguonimi. Degant kietajam kurui, dalis šilumos sunaudojama jam suskaidyti, o degant skystiems degalams, jiems išgarinti. Siekiant pagerinti maišymąsi su oru, degalai deginami išpurkšti.

Pliūpsnio temperatūra yra labai svarbus variklinių alyvų rodiklis. Kuo ji žemesnè, tuo labiau alyva garuoja, daugiau jos išgaruoja ir sudega variklyje, dèl to dažniau reikia papildyti alyvos kieki karteryje, daugiau jos sunaudojama. Iš pliūpsnio temperatūros galima spręsti apie alyvos užsiteršimą kitais produktais. Iš smarkiai sumažèjusios alyvos pliūpsnio temperatūros galima spręsti, kad alyva gali būti užteršta degalais, kurių pliūpsnio temperatūra yra žemesnè.

Degalų pliūpsnio temperatūra nustatoma uždengto tigelio metodu, t. y. juos kaitnant uždarame inde. Kai degalų temperatūra priartèja prie galimos pliūpsnio temperatūros, indas atidengiamas ir prie jo priartinama atvira ugnis. Kai pasiekiama pliūpsnio temperatūra, garai plyksteli ir vèl užgęsta. Alyvų pliūpsnio temperatūra nustatoma atviro tigelio metodu, t. y. jas kaitnant atvirame inde, nes jos sunkiau garuoja.

Naftos produktų užsiliepsnojimo temperatūra paprastai yra šiek tiek $\left(5-10^{\circ} \mathrm{C}\right)$ didesnè už jų pliūpsnio temperatūrą. Užsiliepsnojimo temperatūra nustatoma atvirame inde, nes degimui reikalingas pakankamas oro (deguonies) kiekis.

Taigi pliūpsnio temperatūra apibūdina naftos produktų garavimo (lakumo) ir gaisrines savybes. Degimui būtina, kad degalai gerai maišytųsi su oru. Geriau dega tie degalai, kurių geresnès garavimo (lakumo) savybės, t. y. tie produktai, kurie turi žemesnę pliūpsnio temperatūrą. Vertinant gaisrines savybes, tokie produktai mažiau saugūs. Saugesni yra tie naftos produktai, kurių pliūpsnio temperatūra yra didesnè.

Benzino pliūpsnio temperatūra yra labai žema (minus $27^{\circ} \mathrm{C}-$ minus $43^{\circ} \mathrm{C}$ ), todèl, nesvarbu, kokios jis rūšies, kokie jo gamybos būdai ir pan., gaisrinio saugumo prasme jis yra labai pavojingas produktas, todèl benzinų pliūpsnio temperatūra nenurodoma net jų kokybės pažymèjimuose. 
Dyzelino pliūpsnio temperatūra yra šiek tiek didesnè (plius $30{ }^{\circ} \mathrm{C}$-plius $75^{\circ} \mathrm{C}$ ). Pagal pliūpsnio temperatūrą dyzelinai skirstomi i bendros paskirties ir didesnio saugumo, kuris naudojamas uždarose patalpose, laivuose ir t. t. naudojamiems varikliams. Todèl dyzelinui pliūpsnio temperatūra yra svarbus rodiklis, rodantis gaisrini jų saugumą ir šis rodiklis nurodomas dyzelinų kokybès pažymėjimuose.

Žibalo pliūpsnio temperatūra yra šiek tiek mažesnè nei dyzelino (plius $28^{\circ} \mathrm{C}$ - plius $50^{\circ} \mathrm{C}$ ).

Kaip jau minèta anksčiau, naftos produktų užsiliepsnojimo temperatūra paprastai yra šiek tiek $\left(5-10^{\circ} \mathrm{C}\right)$ didesné už jų pliūpsnio temperatūrą. Savaiminio užsiliepsnojimo temperatūra yra daug didesnè: benzino - apie plius $260-300^{\circ} \mathrm{C}$, žibalo - apie plius $220^{\circ} \mathrm{C}$, dyzelino - apie plius $280-330^{\circ} \mathrm{C}$.

Būtent pagal pliūpsnio temperatūrą naftos produktai skirstomi $\mathfrak{i}$ atitinkamas kategorijas: degiuosius skysčius (kuriu pliūpsnio temperatūra yra plius $60,5-93{ }^{\circ} \mathrm{C}$ ) ir liepsniuosius skysčius (kuriu pliūpsnio temperatūra yra žemesnè kaip plius $60,5^{\circ} \mathrm{C}$ ). Liepsnieji skysčiai dar skirstomi į labai pavojingus; pavojingus; pavojingus aukštesneje temperatūroje.

Degalai priskiriami prie ugniai pavojingų, sveikatai ir aplinkai kenksmingų medžiagų.

4.1 pav. pavaizduotas uždengto tigelio prietaisas pliūpsnio temperatūrai nustatyti. Naftos produktas (pavyzdžiui, dyzelinas) paruošiamas bandymui, iš jo pašalinamas vanduo (pavyzdžiui, valgomaja sausa druska). Prieš bandymą naftos produktas ir tigelis turi turèti temperatūra, ne mažiau kaip $20^{\circ} \mathrm{C}$ žemesnę negu laukiamoji pliūpsnio temperatūra. Naftų produktų, pavyzdžiui, dyzelino, laukiamąją pliūpsnio temperatūrą galima sužinoti iš jų kokybès pažymèjimo (žr. 4.3 pav.). I tigeli iki žiedinès briaunos ipilamas naftos produktas (pavyzdžiui, dyzelinas). Tigelis uždengiamas ir nustatoma temperatūra (tigelyje yra speciali anga termometrūi isstatyti). 


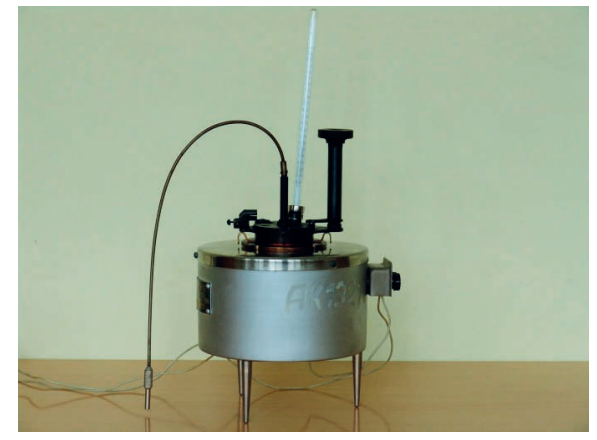

4.1 pav. Uždengto tigelio prietaisas pliūpsnio temperatūrai nustatyti

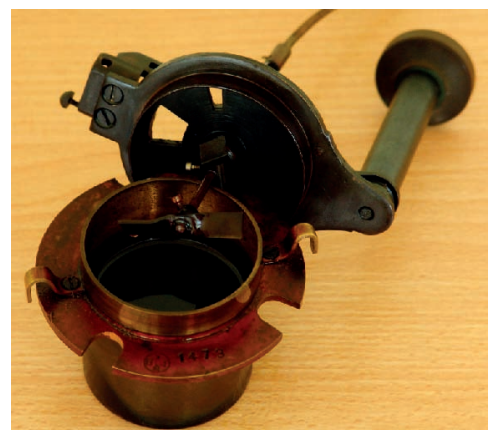

4.2 pav. Tigelis su atidarytu dangteliu

Ijungiamas prietaisas su istatytu tigeliu. Kaitinimo greiti galima reguliuoti autotransformatoriumi. Jeigu naftos produkto pliūpsnio temperatūra yra iki plius $50^{\circ} \mathrm{C}$, jis turi būti kaitinamas $1{ }^{\circ} \mathrm{C} / \mathrm{min}$. greičiu. Jeigu naftos produkto pliūpsnio temperatūra yra nuo plius $50^{\circ} \mathrm{C}$ iki plius $150^{\circ} \mathrm{C}$, jis turi būti kaitinamas $5-8{ }^{\circ} \mathrm{C} / \mathrm{min}$. greičiu. Naftos produktas visą laiką turi būti maišomas maišykle, kuri yra imontuota tigelio dangtelyje (žr. 4.2 pav.), kad produktas būtų vienodai ịkaitęs per visą tigelio tūrị. Kai naftos produkto temperatūra būna $10^{\circ} \mathrm{C}$ žemesnè negu laukiamoji pliūpsnio temperatūra, reikia pradèti uždeginèti naftos produktą. Norint tiksliai nustatyti pliūpsnio temperatūrą, uždeginèti reikia kas $1{ }^{\circ} \mathrm{C}$. Dangtelio langelis atidaromas vienai sekundei ir, priartinus atvirą ugni, bandoma uždegti naftos produktą. Tuo metu nustojama maišyti naftos produktą. Pliūpsnio temperatūra yra ta, kuriai esant, priartinus atvirą ugni, naftos produkto paviršiuje pasirodo pirmoji melsva liepsnelè, kuri greit ir užgęsta. Jeigu tai neivyksta, tigelio langelis uždengiamas, naftos produktas toliau kaitinamas ji maišant ir viskas kartojama iš naujo, kol pasiekiama naftos produkto pliūpsnio temperatūra. 


\begin{tabular}{|c|c|c|c|}
\hline $\begin{array}{l}\text { Kokybės rodikliai } \\
\text { Property }\end{array}$ & $\begin{array}{l}\text { Norma } \\
\text { Norm }\end{array}$ & $\begin{array}{c}\text { Faktiškai } \\
\text { In fact }\end{array}$ & $\begin{array}{l}\text { Metodai } \\
\text { Test method }\end{array}$ \\
\hline $\begin{array}{l}\text { 1. Cetaninis skaičius, ne mažesnis } \\
\text { Cetane number, min. }\end{array}$ & 51,0 & 51,6 & LST EN ISO 5165 \\
\hline $\begin{array}{l}\text { 2. Cetaninis indeksas, ne mažesnis } \\
\text { Cetane index, min. }\end{array}$ & 46,0 & 47,9 & LST EN ISO 4264 \\
\hline $\begin{array}{l}\text { 3. Tankis, esant } 15^{\circ} \mathrm{C}, \mathrm{kg} / \mathrm{m}^{3} \\
\text { Density at } 15^{\circ} \mathrm{C}, \mathrm{kg} / \mathrm{m}^{3}\end{array}$ & $820-845$ & 844,6 & $\begin{array}{l}\text { LST EN ISO } 3675 \\
\text { LST EN ISO } 12185\end{array}$ \\
\hline $\begin{array}{l}\text { 4. Policikliniu aromatinių angliavandenilių } \\
\text { kiekis, \% masės, ne didesnis } \\
\text { Polycyclic aromatic hydrocarbons, } \\
\%(\mathrm{~m} / \mathrm{m}), \text { max. }\end{array}$ & 11 & 5 & LST EN 12916 \\
\hline $\begin{array}{l}\text { 5. Sieros kiekis, } \mathrm{mg} / \mathrm{kg} \text {, ne didesnis } \\
\text { Sulfur content, } \mathrm{mg} / \mathrm{kg} \text {, } \max \text {. }\end{array}$ & 50,0 & 32,6 & LST EN ISO 20846 \\
\hline $\begin{array}{l}\text { 6. Pliūpsnio temperatūra, }{ }^{\circ} \mathrm{C} \text {, aukštesnè kaip } \\
\text { Flash point, }{ }^{\circ} \mathrm{C} \text {, above }\end{array}$ & 55 & 65 & LST EN ISO 2719 \\
\hline $\begin{array}{l}\text { 7. Koksingumas (produkto distiliavimo } \\
10 \% \text { likučio), } \% \text { masès, ne didesnis } \\
\text { Carbon residue (on } 10 \% \text { distilation } \\
\text { residue), } \% \mathrm{~m} / \mathrm{m} \text {, max. }\end{array}$ & 0,30 & 0,03 & LST EN ISO 10370 \\
\hline $\begin{array}{l}\text { 8. Pelenų kiekis, } \% \text { masès, ne didesnis } \\
\text { Ash content, } \% \mathrm{~m} / \mathrm{m} \text {, } \max \text {. }\end{array}$ & 0,01 & 0,01 & LST EN ISO 6245 \\
\hline $\begin{array}{l}\text { 9. Vandens kiekis, } \mathrm{mg} / \mathrm{kg} \text {, ne didesnis } \\
\text { Water content, } \mathrm{mg} / \mathrm{kg} \text {, } \max \text {. }\end{array}$ & 200 & 38 & LST EN ISO 12937 \\
\hline $\begin{array}{l}\text { 10. Teršalu kiekis, } \mathrm{mg} / \mathrm{kg} \text {, ne didesnis } \\
\text { Total contamination, } \operatorname{mg} / \mathrm{kg} \text {, } \max \text {. }\end{array}$ & 24 & 4 & LST EN 12662 \\
\hline $\begin{array}{l}\text { 11. Vario plokštelès korozija ( } 3 \mathrm{~h} \text { esant } \\
\left.50^{\circ} \mathrm{C}\right) \text {, korozijos laipsnis, ne didesnis } \\
\text { Copper strip corrosion }\left(3 \text { at } 50^{\circ} \mathrm{C}\right) \text {, } \\
\text { rating, max. }\end{array}$ & $\begin{array}{c}1 \\
\text { class } 1\end{array}$ & $1 \mathrm{a}$ & LST EN ISO 2160 \\
\hline $\begin{array}{l}\text { 12. Oksiduotų medžiagų kiekis, } \mathrm{g} / \mathrm{m}^{3} \text {, } \\
\text { ne didesnis } \\
\text { Oxidation stability, } \mathrm{g} / \mathrm{m}^{3}, \max \text {. }\end{array}$ & 25 & 7 & LST EN ISO 12205 \\
\hline $\begin{array}{l}\text { 13. Tepumo savybės, patikslintos pagal } \\
\text { skersmens nusidèvejima (wsd 1,4) esant } \\
60{ }^{\circ} \mathrm{C}, \mu \mathrm{m} \text {, ne daugiau } \\
\text { Lubricity, corrected wear scar diameter } \\
\text { (wsd } 1,4 \text { ) at } 60^{\circ} \mathrm{C} \text {, } \mu \text { m, max. }\end{array}$ & 460 & 214 & $\begin{array}{l}\text { LST EN ISO } \\
12156-1\end{array}$ \\
\hline $\begin{array}{l}\text { 14. Klampa, esant } 40^{\circ} \mathrm{C}, \mathrm{mm}^{2} / \mathrm{s} \\
\text { Viscosity, at } 40^{\circ} \mathrm{C}, \mathrm{mm}^{2} / \mathrm{s}\end{array}$ & $2,00-4,50$ & 2,53 & LST EN ISO 3104 \\
\hline $\begin{array}{l}\text { 15. Distiliacijos charakteristikos: } \\
\text { Distillation: }\end{array}$ & & & LST EN ISO 3405 \\
\hline
\end{tabular}

4.3 pav. Dyzelino kokybės pažymėjimas 
Nustačius naftos produkto pliūpsnio temperatūrą, jis gali būti toliau kaitinamas, kad būtų pasiekta jo užsiliepsnojimo temperatūra, kuri paprastai yra apie $5-10^{\circ} \mathrm{C}$ didesnè už pliūpsnio temperatūrą. Ją pasiekus, priartinus ugni, naftos produktas užsiliepsnoja ir dega neužgesdamas. Užsiliepsnojimo temperatūra nustatoma atvirame inde, nes degimui reikalingas pakankamas oro kiekis. Tam, kad naftos produktas degtų neužgesdamas, tigelis turi būti atidarytas. Nesant galimybès jo atidaryti (tigelis yra karštas), galima pasiekus užsiliepsnojimo temperatūrą, bandyti uždegti naftos produktą ir nenuèmus tigelio dangtelio. Nors tokiu atveju dèl oro trūkumo liepsna gali užgesti, bet matyti, kad ne tik įvyksta pliūpsnis, bet naftos produktas toliau dega ir užgesta tik dèl to, kad neužtenka degimui būtino oro kiekio. 


\section{ALYVOS IR JŲ KOKYBĖS RODIKLIAI}

Rengiant ši skyrių, panaudoti literatūros šaltiniai (Baltėnas et al. 1998; Bureika et al. 2008; Jučas 1992; Mang, Dresel 2007; Мартынюк et al. 1993; Синельников, Балабанов 2005; Стуканов 2003).

Alyvoms yra svarbios klampuminès, tepimo, antioksidacinès, plovimo, antikorozinès, putojimo, apsauginès, gaisrinès ir kitos savybès. Kiekviena savybė įvertinama keliais rodikliais, kurie apibūdina alyvos kokybę.

Alyvoms labai svarbios klampuminès savybės, kurios vertinamos tokiais rodikliais: klampa esant darbo ir aplinkos temperatūrai, stingimo temperatūra, klampos indeksu.

Klampa - tai rodiklis įvertinantis alyvos vidaus trinti. Nuo alyvos klampos priklauso mechanizmų trinties nuostoliai ir išdilimo mastas. Hidraulinėms alyvoms ir kitoms alyvoms, dirbančioms palyginti lengvesnèmis sąlygomis, nelabai aukštoje temperatūroje, paprastai nustatoma kinematinè klampa plius $40{ }^{\circ} \mathrm{C}$ temperatūroje. Variklinių ir transmisinių alyvų, naudojamų sunkesnèmis sąlygomis, aukštesnèje temperatūroje, nustatoma kinematinè klampa plius $100{ }^{\circ} \mathrm{C}$ temperatūroje, nes reikia žinoti, kokia bus šių alyvų klampa aukštoje temperatūroje, artimoje jų darbinei temperatūrai.

Stingimo temperatūra - tai rodiklis alyvos ribiniam tekumui žemoje temperatūroje įvertinti. Tai tokia temperatūra, kai iki jos atšaldyta alyva pasidaro nepaslanki. Naftos produktų stingimo temperatūra nustatoma, ipilus juos i standartini mègintuvèli, kurio skersmuo $20 \mathrm{~mm}$, kad skysčio aukštis būtų $30 \mathrm{~mm}$, ir pakreipus $45^{\circ} \mathrm{kampu}$. Stingimo tenperatūra yra tuomet, kai naftos produkto paviršiaus padètis nesikeičia 1 min. Iš alyvos stingimo temperatūros sprendžiama apie jos išpilstymo, transportavimo ir naudojimo galimybes žiemą.

Klampos indeksas - tai rodiklis alyvos klampos priklausomybei nuo temperatūros îvertinti. Jis nustatomas naudojant dvi etalonines alyvas, iš kurių vienos klampa labai priklauso nuo temperatūros (jos klampos indeksas $K=0$ ), o kitos mažai (jos klampos indeksas 
$K=100$ ). Šių etaloninių alyvų klampa plius $100^{\circ} \mathrm{C}$ temperatūroje yra vienoda ir ji turi būti tokia pati kaip ir bandomosios alyvos, kurios klampos indeksą reikia nustatyti. Norint nustatyti alyvos klampos indeksa, reikia žinoti bandomosios alyvos kinematinę klampą esant plius $40^{\circ} \mathrm{C}$ ir plius $100^{\circ} \mathrm{C}$ temperatūrai. Tada pagal jos klampą, esant plius $100^{\circ} \mathrm{C}$ temperatūrai, parenkamos atitinkamos etaloninès alyvos ir nustatomos (arba specialioje literatūroje surandamos) jų klampos esant plius $40{ }^{\circ} \mathrm{C}$ temperatūrai. Bandomosios alyvos klampos indeksą galima apskaičiuoti pagal tokią formulę:

$$
K=\frac{\mathrm{v}_{1}-\mathrm{v}_{3}}{\mathrm{v}_{1}-\mathrm{v}_{2}} \cdot 100 ;
$$

čia: $v_{1}$-alyvos, kurios klampa labai priklauso nuo temperatūros (klampos indeksas $K=0$ ), kinematinè klampa esant plius $40{ }^{\circ} \mathrm{C}$ temperatūrai, $\mathrm{mm}^{2} / \mathrm{s}(\mathrm{cSt})$;

$v_{2}$ - alyvos, kurios klampa mažai priklauso nuo temperatūros (klampos indeksas $K=100$ ), kinematinè klampa esant plius $40{ }^{\circ} \mathrm{C}$ temperatūrai, $\mathrm{mm}^{2} / \mathrm{s}(\mathrm{cSt})$;

$v_{3}$ - bandomosios alyvos, kurios klampos indeksas nustatomas, kinematinè klampa esant plius $40^{\circ} \mathrm{C}$ temperatūrai, $\mathrm{mm}^{2} / \mathrm{s}$ $(\mathrm{cSt})$.

Kuo alyvos klampos indeksas $K$ didesnis, tuo alyvos klampa mažiau priklauso nuo temperatūros. Tokia alyva žiemą mažiau stingsta, todèl lengviau paleisti varikli. Tai ypač svarbu visasezonèms alyvoms, kurių klampos indeksas būna didesnis. Sintetiniu alyvų klampos indeksas didesnis nei mineralinių. Kokybiškų visasezonių, sintetinių alyvų klampos indeksas $K=115-160$, o sezoninių, mineralinių alyvų jis paprastai būna iki 100. Esant kritinèms temperatūroms (labai žemoms ir labai aukštoms) alyvos, kurių klampos indeksas didelis yra geresnès, nes esant žemai temperatūrai ne taip greitai stingsta, o esant aukštai temperatūrai nesuskystèja, todèl geriau apsaugo varikli nuo dilimo. 
Kadangi klampuminės savybės alyvoms yra labai svarbios, dažnai nubraižomos alyvų grafinès klampos priklausomybès nuo temperatūros $v=f(t)$. Tuomet pagal šias priklausomybes galima lyginti alyvas tarpusavyje ir spresti apie jų savybes.

Alyvos klasifikuojamos pagal naudojimo vietą (hidraulinės, variklinès, transmisinès), pagaminimo būdą (mineralinès, pusiau sintetinès, sintetinès) ir t. t., taip pat yra kitokių tepimo medžiagu (konsistenciniai tepalai ir t. t.), visų jų skirtingos savybės, eksploatacijos sąlygos, kiti ypatumai. 5.1 pav. pavaizduoti îvairiu rūšių alyvų ir tepimo medžiagų pavyzdžiai.

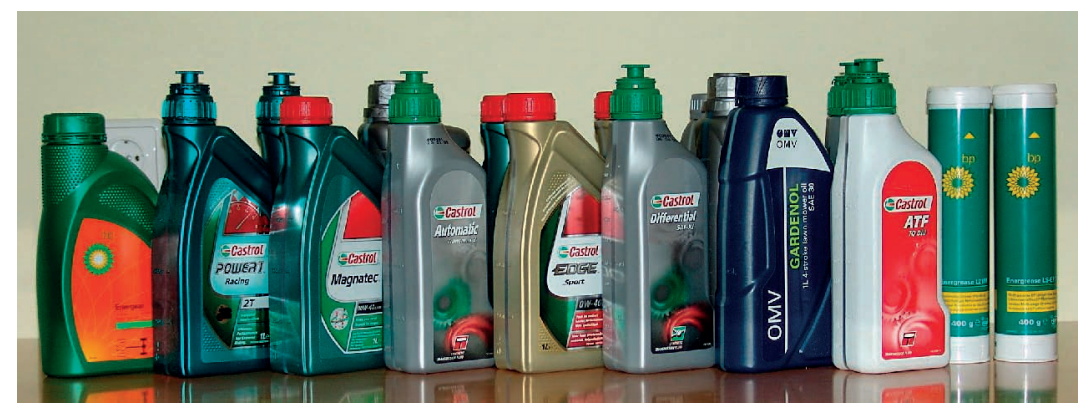

5.1 pav. Ivairių rūšių alyvų ir tepimo medžiagų pavyzdžių rinkinys

Paprastai nustatoma ịvairių rūšių alyvų kinematinè klampa esant aplinkos temperatūrai $v_{t}$ ir kinematinè klampa esant darbo temperatūrai: $v_{40}$ (esant $40^{\circ} \mathrm{C}$ temperatūrai) - hidraulinių ir kitų alyvų, naudojamų palyginti lengvesnèmis sąlygomis, esant nelabai aukštai temperatūrai; $v_{100}$ (esant $100{ }^{\circ} \mathrm{C}$ temperatūrai) - variklinių ir transmisiniu alyvų, naudojamų sunkesnèmis sąlygomis, esant aukštesnei temperatūrai. Esant būtinybei gali būti apskaičiuota dinaminè klampa esant atitinkamai temperatūrai.

Alyvoms pliūpsnio temperatūra turi būti nustatoma atvirame inde, t. y. atviro tigelio prietaisu.

5.1 lentelèje nurodytos alyvų rūšys ir alyvų kokybės rodikliai. 
5.1 lentelė. Ištirtų alyvų kokybės rodikliai

\begin{tabular}{|c|c|c|c|c|c|}
\hline Alyva & $\begin{array}{c}\text { Tankis } \\
\rho_{t}, \\
\mathrm{~kg} / \mathrm{m}^{3}\end{array}$ & $\begin{array}{l}\text { Kinematine } \\
\text { klampa aplin- } \\
\text { kos tempera- } \\
\text { tūroje } v_{t}, \\
\text { cSt }\left(\mathrm{mm}^{2} / \mathrm{s}\right)\end{array}$ & $\begin{array}{c}\text { Kinematinè } \\
\text { klampa darbo } \\
\text { temperatūroje } \\
\mathrm{v}_{40} \text { arba } \mathrm{v}_{100} \\
\mathrm{cSt}\left(\mathrm{mm}^{2} / \mathrm{s}\right)\end{array}$ & $\begin{array}{l}\text { Dinaminé } \\
\text { klampa } \\
\eta_{t}, \\
\mathrm{cP}(\mathrm{mPa} \cdot \mathrm{s})\end{array}$ & $\begin{array}{l}\text { Pliūpsnio } \\
\text { temperatū- } \\
\text { ra, }{ }^{\circ} \mathrm{C}\end{array}$ \\
\hline $\begin{array}{l}\text { Mineralinè va- } \\
\text { riklinè alyva } \\
\text { (nurodyti SAE } \\
\text { klampos laipsni) }\end{array}$ & & & & & \\
\hline $\begin{array}{l}\text { Pusiau sintetinè } \\
\text { variklinè alyva } \\
\text { (nurodyti SAE } \\
\text { klampos laipsni) }\end{array}$ & & & & & \\
\hline $\begin{array}{l}\text { Sintetinè varikli- } \\
\text { nè alyva } \\
\text { (nurodyti SAE } \\
\text { klampos laipsni) }\end{array}$ & & & & & \\
\hline $\begin{array}{l}\text { Mineralinè trans- } \\
\text { misine alyva } \\
\text { (nurodyti SAE } \\
\text { klampos laipsni) }\end{array}$ & & & & & \\
\hline $\begin{array}{l}\text { Pusiau sintetinè } \\
\text { transmisinė alyva } \\
\text { (nurodyti SAE } \\
\text { klampos laipsni) }\end{array}$ & & & & & \\
\hline $\begin{array}{l}\text { Sintetine trans- } \\
\text { misinè alyva } \\
\text { (nurodyti SAE } \\
\text { klampos laipsni) }\end{array}$ & & & & & \\
\hline . & & & & & \\
\hline
\end{tabular}

Norint įvertinti ịvairių rūšių (mineralinių, pusiau sintetinių ir sintetinių) alyvų klampumo savybes ir palyginti jas tarpusavyje, nubraižomos grafinès alyvos (pavyzdžiui, variklinés alyvos) klampos priklausomybės nuo temperatūros $v=f(t)$, kaip pavaizduota 5.2 pav. Siekiant jas kuo tiksliau nubraižyti, papildomai nustatomos alyvos klampos esant tam tikroms temperatūroms, iki atitinkamos temperatūros padidinant (sumažinant) termostato temperatūrą. Analizuojant 
nubraižytas grafines priklausomybes, nustatomi i̇vairių alyvų rūšių pranašumai ir trūkumai.

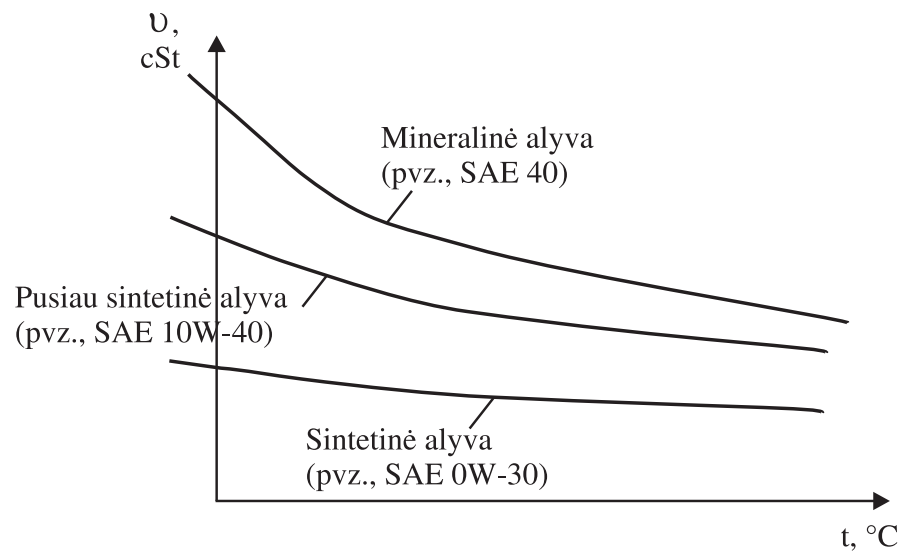

5.2 pav. Ivairių rūšių alyvų kinematinès klampos priklausomybès nuo temperatūros $v=f(t)$ 


\section{DVIEJŲ SKYSČIO KOMPONENTŲ MIŠINIO PARUOŠIMAS. DEGALŲ OKTANINIO IR CETANINIO SKAIČIU APSKAIČIAVIMAS}

Rengiant ši skyrių, panaudoti literatūros šaltiniai (Baltėnas et al. 1998; Jučas 1992; Мартынюк et al. 1993; Стуканов 2003).

Paprastai benzinas gaminamas naudojant mažo oktaninio skaičiaus bazini benziną ir pridedant i jị didelio oktaninio skaičiaus komponentus, tokius kaip izooktanas, metiltretbutilo eteris (MTBE), etiltretbutilo eteris (ETBE), cheminiais perdirbimo būdais pagamintus komponentus, priedus. Apie benzino oktanini skaičių ir jo nustatymą išsamiau aprašyta 1 skyriuje.

Taigi, gaminant benziną, maišomi skirtingais būdais gauti skirtingų oktaninių skaičių komponentai. Norint gauti tam tikro oktaninio skaičiaus benziną, reikia žinoti, kokiomis proporcijomis sumaišyti šiuos komponentus. Tai galima nustatyti pagal tokias formules:

$$
\begin{gathered}
A_{k}=\frac{n_{r}-n_{n k}}{n_{k}-n_{n k}} \cdot 100 ; \\
A_{n k}=100-A_{k} ;
\end{gathered}
$$

čia: $A_{k}$ - reikalingas kokybiško benzino kiekis, tūrio \%;

$n_{r}$ - reikalingas mišinio oktaninis skaičius (OST);

$n_{k}-$ kokybiško benzino oktaninis skaičius (OST);

$n_{n k}-$ nekokybiško benzino oktaninis skaičius (OST);

$A_{n k}$ - reikalingas nekokybiško benzino kiekis, tūrio \%.

Automobilių varikliams paprastai naudojami benzinai, kurių oktaninis skaičius, nustatytas tiriamuoju metodu (OST), yra 92, 95, 98, o aviacinių benzinų oktaninis skaičius yra didesnis. Todèl, norint pagaminti benziną, kurio oktaninis skaičius, pavyzdžiui, 92, 95 ar 98, paimamas tam tikras kiekis $A_{n k}$ nekokybiško (bazinio) benzino, kurio oktaninis skaičius yra mažesnis už reikalingą mišinio oktanini skaičių $\left(n_{n k}<n_{r}\right)$, ir sumaišoma su tam tikru kiekiu $A_{k}$ kokybiško (aukšto 
oktaninio skaičiaus) benzino, kurio oktaninis skaičius yra didesnis už reikalingą mišinio oktanini skaičių $\left(n_{k}>n_{r}\right)$.

Tokiu pat principu, naudojant tas pačias formules, galima nustatyti ne tik benzino, bet ir kitų dviejų skirtingų komponentų mišiniu reikiamą sudèti. Tokiu atveju $n_{r}, n_{k}, n_{n k}$ vietoje oktaninio skaičiaus irašomi kito skysčių rodiklio atitinkamos reikšmès.

Gaminant techninius skysčius dažnai naudojami skirtingų savybių skysčių mišiniai, kurių sudèti apibūdina tam tikras parametras, pavyzdžiui, tankis. Taip gaminami elektrolitai, aušinimo skysčiai ir t. t.

Benzino oktanini skaičių, nustatytą varikliniu metodu (OSV) ir tiriamuoju metodu (OST), galima apskaičiuoti pagal tokias empirines formules:

$$
\begin{gathered}
O S V=125,4-\frac{413}{\varepsilon}+0,183 d \\
O S T=78+0,25 d-\frac{6000}{\varepsilon^{3}}
\end{gathered}
$$

čia: $\varepsilon$-variklio suslègimo laipsnis;

$d$ - variklio cilindro skersmuo, $\mathrm{mm}$.

Tarp oktaninio ir cetaninio skaičių yra toks ryšys:

$$
O S V=120-2 C S
$$

čia: $O S V$ - oktaninis skaičius, nustatytas varikliniu metodu;

$C S-$ cetaninis skaičius.

Iš formulès (6.5) matyti, kad kuo didesnis cetaninis skysčio skaičius, tuo mažesnis oktaninis jo skaičius, ir atvirkščiai. Tai paaiškinama tuo, kad dyzeliniam varikliui naudojamiems degalams reikia gero užsidegamumo, t. y. priešingu savybių nei benzininiam varikliui naudojamiems degalams, kurie turi priešintis detonacijai, t. y. išankstiniam savaiminiam užsidegimui.

Cetanini degalų skaičių galima apskaičiuoti pagal tokią formulę:

$$
C S=0,85 A l+0,1 C k-0,2 A r ;
$$

čia: $A l, C k, A r$-atitinkamai, alkanų, cikloalkanų ir arenų grupių angliavandenilių masè degaluose, $\%$. 
Iš formulès (6.6) matyti, kad dyzeline, kuriam yra svarbus didelis cetaninis skaičius, labiausiai pageidaujami alkanų grupės angliavandeniliai, šiek tiek mažiau - cikloalkanų grupès angliavandeniliai ir nepageidaujami arenų grupės angliavandeniliai. Benzine, atvirkščiai, alkanų ir cikloalkanų grupių angliavandeniliai yra nepageidaujami, o pageidaujami arenų grupès, taip pat izoalkanų grupès angliavandeniliai.

Pagal benzino reikiamo oktaninio skaičiaus (OST) $n_{r}$ ir nekokybiško (žemesnio oktaninio skaičiaus) bazinio benzino oktaninio skaičiaus (OST) $n_{n k}$ reikšmes gali būti parenkamas kokybiško (aukštesnio oktaninio skaičiaus) benzino oktaninis skaičius (OST) $n_{k}$. Pagal formules (6.1) ir (6.2) apskaičiuojama, kokiomis proporcijomis reikia sumaišyti komponentus, kad būtu gautas reikiamo oktaninio skaičiaus benzinas, t. y. apskaičiuojami reikiamas kokybiško benzino kiekis $A_{k}$ ir nekokybiško benzino kiekis $A_{n k}$.

Pagal variklio suslègimo laipsnio $\varepsilon$ ir variklio cilindro skersmens $d$ reikšmes, panaudojant formules (6.3) ir (6.4), gali būti apskaičiuojamos varikliui tinkamo benzino oktaninio skaičiaus, nustatyto varikliniu metodu (OSV) ir tiriamuoju metodu (OST), orientacinès reikšmès. 


\section{VANDENS DISTILIAVIMAS}

Rengiant šị skyrių, panaudotas literatūros šaltinis (Jakubkienė, Brukštus 2005).

Distiliavimas - lakių skysčių išskirstymas i skirtingu lakumu pasižyminčius komponentus. Šio proceso metu distiliavimo mišinys yra kaitinamas ir ji sudarantys junginiai paeiliui, virimo temperatūros didèjimo tvarka, iš skysčio pereina i garus, kurie, patekę i kondensatorių, vèl virsta skysčiu, o jis surenkamas i priimtuvą. Distiliavimas dar naudojamas tirpikliui nugarinti nuo ekstrahuotos medžiagos. Nugarinimui dažniausiai naudojami rotaciniai garintuvai. Virš garuojančių skysčių tarp skysčio ir garų fazių nusistovi pusiausvyra, kartu tam tikras garų slègis. Garų slègio dydis priklauso nuo medžiagos (skysčio) prigimties ir temperatūros. Kylant temperatūrai, garų slègis virš skysčio sparčiai didèja. Temperatūra, kurioje garu slėgis susilygina su išoriniu slėgiu, pavyzdžiui, atmosferos, yra vadinama virimo temperatūra (sutrumpintai vir. t.). Kreivès taškas, atitinkantis $760 \mathrm{~mm} \mathrm{Hg}$ stulpelio slejgi, yra tam tikros medžiagos virimo temperatūra normaliame (atmosferos) slègyje, aišku, jei ta medžiaga termiškai atspari ir kaitinama iki tos temperatūros nesuskyla. Tokia vandens temperatūra yra plius $100{ }^{\circ} \mathrm{C}$. Tačiau esant $200 \mathrm{~mm} \mathrm{Hg}$ stulpelio slègiui vanduo užvirs plius $66^{\circ} \mathrm{C}$ temperatūroje, todèl nurodant virimo temperatūrą reikia nurodyti ir slègi, kuriame ji buvo nustatyta. Atmosferos slègis paprastai nenurodomas, o virimo temperatūra esant tokiam slègiui vadinama normalia virimo temperatūra. Reikia atminti, kad atmosferos slègis paprastai svyruoja $\pm 20 \mathrm{~mm} \mathrm{Hg}$ stulpelio ribose, o jam pakitus $10 \mathrm{~mm}$, virimo temperatūra pakinta apytikriai $0,5^{\circ} \mathrm{C}$.

Distiliavimo procesą galima suskirstyti i paprastaji ir frakcini.

Paprastasis distiliavimas naudojamas vienam pakankamai lakiam skystam junginiui išgryninti - pašalinti jame ištirpusias kietas arba nelakias medžiagas bei atskirti dvi skystas medžiagas, kurių virimo temperatūra skiriasi daugiau kaip $80^{\circ} \mathrm{C}$. Taip pat paprastasis distiliavimas naudojamas medžiagos grynumui patikrinti nustatant jos virimo temperatūrą. Nustatyta virimo temperatūra visada palyginama su virimo temperatūros reikšme, nurodyta žinyne arba specialioje literatūroje. 
Distiliuojant medžiagas, kurių virimo temperatūra žemesnẻ kaip plius $120^{\circ} \mathrm{C}$, naudojamas vandens kondensatorius su tekančiu vandeniu. Medžiagoms, kurių virimo temperatūra yra plius $120-160{ }^{\circ} \mathrm{C}$, naudojamas kondensatorius su netekančiu vandeniu, o esant aukštesnei kaip plius $160{ }^{\circ} \mathrm{C}$ virimo temperatūrai - oro kondensatorius (12-16 mm skersmens stiklinis vamzdelis). Distiliuodami šiuo būdu išskiriame pavienius homogeninių skystų medžiagų komponentus, besiskiriančius virimo temperatūra. Frakcinio distiliavimo aparatūra skiriasi nuo paprastojo distiliavimo aparatūros tuo, kad tarp kolbos ir kondensatoriaus statoma rektifikavimo kolona arba deflegmatorius, kuriuose ir atskiriami mišinio komponentai.

Organinès medžiagos, turinčios aukštą virimo temperatūrą ir skylančios joje arba arti jos, distiliuojamos sumažinus slègi (vakuume). Jei distiliuojama sumažinus slègi, sumažèja junginio virimo temperatūra ir kartu jo skilimo galimybė. Žinoma orientacinè taisyklè: sumažinus slègi pusiau, virimo temperatūra sumažèja maždaug $15-20{ }^{\circ} \mathrm{C}$. Esant 5-10 mm Hg stulpelio slègiui, junginių virimo temperatūros sumažejja $100-150^{\circ} \mathrm{C}$. Distiliavimo vandens garais metodas taikomas medžiagoms,kuriu aukštos virimo temperatūros, ir netirpioms arba blogai tirpioms vandenyje, išskirti. Tokios medžiagos distiliuojasi leidžiant per jas vandens garus.

7.1 pav. pavaizduotas vandens distiliavimo aparatas DP 1500. Prieš naudojimą patikrinama, ar distiliatoriaus žarnelès yra tvarkingai sujungtos su vandens tiekimo sistema.

Turi būti issitikinama, kad:

- pagrindinis jungiklis 1 yra išjungtas (t. y. žalia lemputė nešviečia);

- apsauginis gaubtelis 2 nuimtas;

- išleidimo anga 3 ir vandens surinkimo indo išleidimo anga yra uždarytos.

Tada:

1. Ijungiamas aparato kištukas i elektros lizdą.

2. Sureguliuojamas vandens tiekimas. Lètai atsukamas vandens tiekimo čiaupas taip, kad mažas vandens kiekis pratekètu pro vandens pertekliaus išleidimo angą (apytiksliai 0,5-1 1/min.). 
3. Kai vanduo garintuve 4 beveik užsemia kaitinimo spirales, jjungiamas aparatas (mygtukas 1 ). Žalia lempute 5 užsidega.

4. Kai tik vanduo garintuve ima virti, išmatuojama virimo temperatūra, tada po truputị sumažinamas vandens tiekimas prisukant čiaupa, kol garai pradès veržtis per dujų išleidimo angą 6 aparato viršuje. Po truputi didinamas vandens tiekimas tol, kol garai nustos veržtis per angą - vandens tiekimas optimaliai sureguliuotas.

5. Distiliuojamas vandens kiekis $20 \mathrm{ml}$.

6. Vandens tiekimas nutraukiamas užsukant čiaupą.

7. Išjungiamas pagrindinis jungiklis 1 , nuimamas apsauginis gaubtelis 2 , uždaromos išleidimo 3 ir vandens surinkimo indo išleidimo angos.

8. Ištraukiamas aparato kištukas iš elektros lizdo.

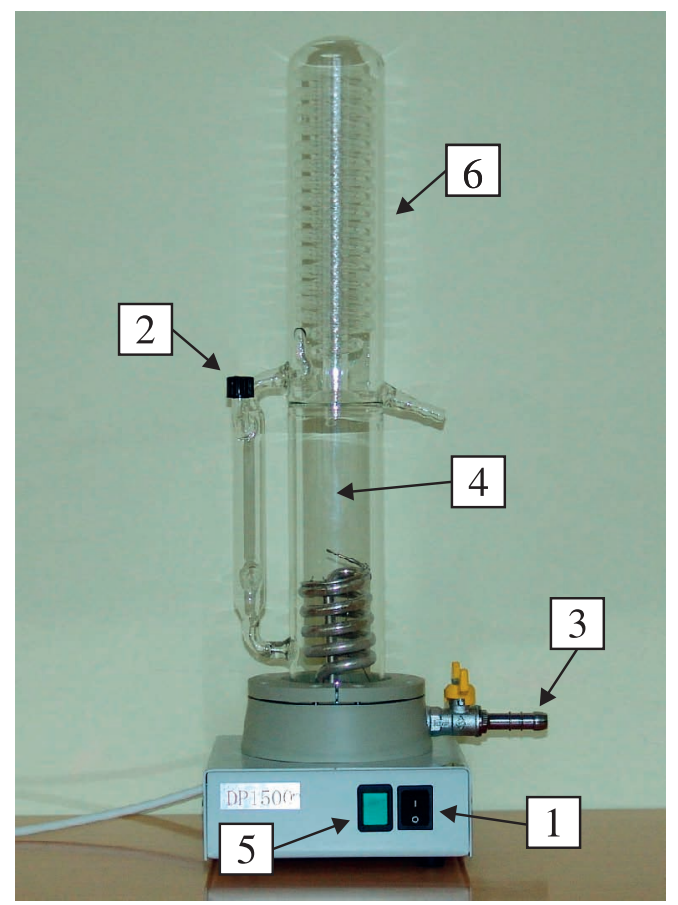

7.1 pav. Vandens distiliavimo aparatas DP 1500:

1 - pagrindinis jungiklis, 2 - apsauginis gaubtelis, 3 - išleidimo anga, 4 - garintuvas, 5 - žalia lemputè, 6 - dujų išleidimo anga 


\section{NAFTOS PRODUKTŲ RŪGŠTINGUMAS IR ŠARMINGUMAS. JŲ NUSTATYMAS}

Rengiant ši skyrių, panaudoti literatūros šaltiniai (Baltėnas et al. 1998; Jučas 1992).

Korozingumas apibūdina degalų ir jų degimo produktų cheminę sąveiką su metalais, iš kurių pagamintos variklių detalès bei degalu transportavimo ir laikymo priemonès. Angliavandeniliai yra chemiškai inertiški. Degalų cheminis aktyvumas priklauso nuo juose esančių deguonies ir sieros junginių. Iš deguoninių junginių cheminiu agresyvumu pasižymi nafteninès rūgštys ir nestabilių angliavandenilių oksidacijos produktai, susidarantys laikant degalus.

Korozinis degalų aktyvumas įvertinamas tokiais rodikliais: rūgštumu, vandenyje tirpių rūgščiu ir šarmų kiekių, bendru sieros kiekiu, tiolių (merkaptanų) kiekiu, vandenilio sulfido kiekiu, bandymu vario plokštele.

Rūgštumas (rūgštinis skaičius) - rodiklis organinių rūgščių bendram kiekiui naftos produktuose įvertinti. Be grynų angliavandenilių, naftos produktuose būna ir deguoninių junginių - organinių rūgščių, fenolių ir dervų. Organinès rūgštys (skruzdžių $\mathrm{HCOOH}$, acto $\mathrm{CH}_{3} \mathrm{COOH}$, propiono $\mathrm{C}_{2} \mathrm{H}_{5} \mathrm{COOH}$ ir kt.), lyginant su vandenyje tirpiomis mineralinėmis rūgštimis (jų alyvoje neturi būti), yra silpnos rūgštys. Juodujų metalų jos beveik neveikia, tačiau kai kuriuos spalvotuosius (pvz., šviną, cinką, varị), kurių būna guolių lydinių sudètyje, koroduoja labai aktyviai. Agresyvesnès yra mažesnès molekulinès masės rūgštys. Organinès rūgštys susidaro oksiduojantis (ypač aukštoje temperatūroje) angliavandeniliams - visų pirma nestabiliems. Veikiant varikliui, alyvos rūgštumas, kartu ir korozingumas, laipsniškai didèja. Susidarančioms rūgštims neutralizuoti i alyvas dedama šarminių priedų. Dyzelinių variklių maitinimo sistemoje spalvotujų metalų nèra, todèl dyzelinių degalų rūgštumas daugiau apibūdina degalų oksidacijos laipsni.

Degalų rūgštumas $\left(\mathrm{mg} \mathrm{KOH} / 100 \mathrm{~cm}^{3}\right)$ - tai kalio šarmo kiekis (mg), kuris neutralizuoja visus rūgštinius junginius, esančius $100 \mathrm{~cm}^{3}$ 
degalų. Alyvos rūgštinis skaičius (mg KOH/g) - tai kalio šarmo kiekis (mg), kuris neutralizuoja visus rūgščius junginius, esančius $1 \mathrm{~g}$ alyvos.

Organinės rūgštys gerai tirpsta visuose naftos produktuose ir organiniuose tirpikliuose, kai kurios - ir vandenyje. Nustatant rūgščiu kieki, jos ištirpinamos $85 \%$ etanolio tirpale (šildant), ir ekstraktas titruojamas 0,05 normalingumo kalio šarmo tirpalu etanolyje. Taip neutralizuojamos nafteninès rūgštys, kurios patenka į naftą, rūgštys, kurios susidaro oksiduojantis angliavandeniliams, ir rūgštys - sieros junginių oksidacijos produktai, pavyzdžiui, sulforūgštys $\mathrm{RS}_{3} \mathrm{H}$.

Vandenyje tirpių rūgščių ir šarmų kiekis - rodiklis vertinant, kiek naftos produktuose yra vandenyje tirpių rūgščiu ir šarmų.

Vandenyje tirpios rūgštys ir šarmai koroduoja metalus. Ypač pavojingos mineralinès rūgštys - sieros $\mathrm{H}_{2} \mathrm{SO}_{4}$ azoto $\mathrm{HNO}_{3}$, druskos $\mathrm{HCl}$ ir kt., kurių vandeniniai tirpalai ardo beveik visus metalus. Organinès rūgštys veikia tik spalvotuosius metalus, kuriuos, be to, veikia ir šar$\mathrm{mu}$ - kalio $\mathrm{KOH}$, natrio $\mathrm{NaOH}$, ličio $\mathrm{LiOH}$ ir kt. vandeniniai tirpalai. Todèl ir mineralinių, ir vandenyje tirpstančių organinių rūgščių, ir šarmu naftos produktuose neturi būti. Organinès rūgštys gali susidaryti oksiduojantis naftos produktams, mineralinès (pvz., $\mathrm{H}_{2} \mathrm{SO}_{4}$ ir $\mathrm{H}_{2} \mathrm{SO}_{3}$ ), - naudojant sieringus degalus. Be to, rūgštimis ir šarmais gali užsiteršti netinkamai transportuojami ir laikomi naftos produktai.

Naftos produktuose esančios rūgštys ir šarmai ištirpinami vandenyje ir vandens ekstrakto rūgštingumas tikrinamas indikatoriais arba $\mathrm{pH}$-metru. Skirstymo inde sumaišoma $50 \mathrm{~cm}^{3}$ degalų su tokiu pat distiliuoto vandens kiekiu ir mišinys gerai suplakamas, kad rūgštys ir šarmai ištirptų vandenyje. Vandeniui nusistojus, po $2 \mathrm{~cm}^{3}$ vandens ekstrakto ipilama ị du mègintuvèlius. Po to i vieną mėgintuvèli ilašinami du lašai metiloranžo, i kitą - trys lašai fenolftaleino. Jeigu kuriame nors mėgintuvèlyje vanduo nusidažo rausva spalva, tai metiloranžas rodo, kad degaluose yra rūgščių, fenolftaleinas - šarmų. Jeigu matuojama pH-metru, rūgščių tirpalu pH yra mažesnis kaip 5, šarminių tirpalų - didesnis kaip 9. Jei vanduo būna kitokios spalvos arba pH-metru nustatytas $\mathrm{pH}$ yra tarp 5 ir 9, degaluose nei rūgščiu, nei šarmų nèra. 
8.1 pav. pavaizduotas $\mathrm{pH}$ matuoklis. Prieš naudojimą patikrinama, ar $\mathrm{pH}$ matuoklio elementai tvarkingai sujungti.

Atliekamas prietaiso kalibravimas:

1. Ijungiamas $\mathrm{pH}$ matuoklis mygtuku START;

2. Paspaudžiamas mygtukas SETUP, kol pradeda mirksèti MTC ženklas, spaudžiant mygtuką SETUP pasirenkama norima temperatūra ir klavišais pirmyn ir atgal pasirenkama buferių grupè (B1, B2, B3), jos pasirinkimas patvirtinamas paspaudus mygtuką READ;

3. Imerkiamas elektrodas ị kalibravimo buferi, palaukiama 15-20 sekundžių ir paspaudžiamas mygtukas CAL, ant ekrano atsiranda kalibravimo ženklas.

pH matuoklio elektrodas nuplaunamas distiliuotu vandeniu, imerkiamas i indą su naftos produktu ir paspaudžiamas READ mygtukas. Ekrane matoma mėginio $\mathrm{pH}$ reikšmè, paspaudus MODE mygtuką nustatomas méginio oksidacijos - redukcijos potencialas (ORP), kuris apibūdina mėginio pajėgumą atiduoti ar prisijungti elektrodus.

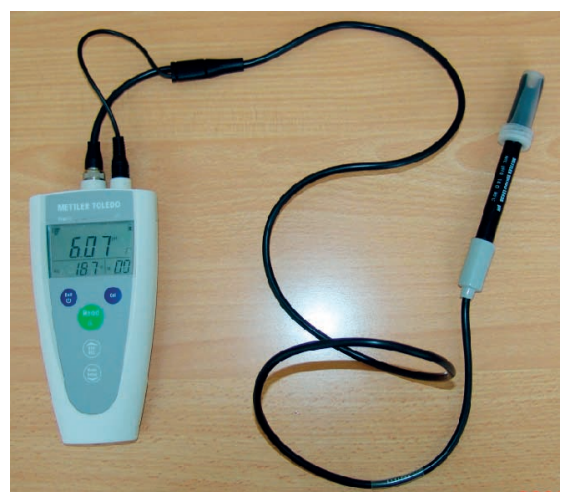

8.1 pav. pH matuoklis Five go

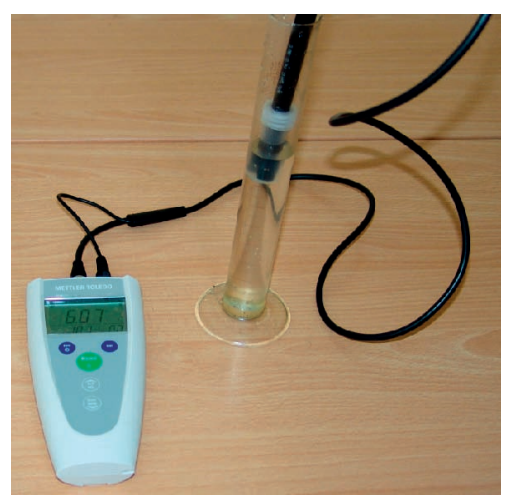

8.2 pav. Naftos produkto rūgštingumo nustatymas 


\section{AUŠINIMO SKYSČIO UŽŠALIMO TEMPERATŪRA IR ELEKTROLITO TANKIS}

Rengiant ši skyrių, panaudoti literatūros šaltiniai (Jučas 1992; Мартынюк et al. 1993; Стуканов 2003).

Aušinimo skysčiai yra naudojami vidaus degimo varikliams aušinti. Sudegus degalams, ne visa šiluma pavirsta naudingu darbu. Ji pasiskirsto taip: naudingam darbui - 26 (benzininis variklis) ir $35 \%$ (dyzelinis variklis), mechaninei trinčiai -8 ir $10 \%$, išmetama su deginiais 35 ir $28 \%$, išsisklaido aušinimo sistemoje - 31 ir $27 \%$. Tampa aišku, kad trečdalị vidaus degimo variklio išskiriamos šilumos turi išsisklaidyti aušinimo sistemoje.

Aušinimo efektyvumą lemia skysčio fizikinès bei cheminès savybès, ypač skysčio šiluminė talpa ir laidumas. Didesnès šiluminès talpos skystis gali sukaupti daugiau šilumos, todèl jo mažiau reikia, didesnio laidumo - greičiau šilumą atiduoti, todèl skystis gali lěčiau cirkuliuoti. Aušinimo skystis turi būti talpus ir laidus šilumai, optimalios klampos, kad lengvai cirkuliuotų ir netekètų per sujungimus. Jo užšalimo temperatūra turi būti $5-10{ }^{\circ} \mathrm{C}$ žemesnè nei aplinkos galima žemiausia temperatūra, kad žiemą neužšaltų ir virimo temperatūra $-15-20{ }^{\circ} \mathrm{C}$ didesnè nei galima didžiausia darbo temperatūra, kad neišgaruotų.

Dažniausiai naudojami aušinimo skysčiai - vanduo ir antifrizas.

Vanduo - paprasčiausias aušinimo skystis, bet turintis tris pagrindinius trūkumus:

1. Užšąla žemesnejje kaip $0{ }^{\circ} \mathrm{C}$ temperatūroje ir jo tūris padideja maždaug $10 \%$, taigi šaldamas jis gali suardyti variklio bloką ir radiatorių;

2. Turi žemą virimo temperatūrą (plius $100^{\circ} \mathrm{C}$ );

3. Vandenyje yra daug ištirpusių druskų, kurios, padengdamos aušinimo sistemos vidini paviršių, blogina variklio aušinimą.

Antifrizas - tai neužšąlantis skystis - etilenglikolio tirpalas vandenyje ir priedai korozijai mažinti. Šiaurès Amerikoje ir kitose šalyse vietoje etilenglikolio dar vartojamas propilenglikolis. Antifrizo egzistuoja daug rūšių, turbūt geriausiai žinomas iš jų yra tosolas (rus. TOC - 
технология ограниченного синтеза [liet. ribotos sintezès technolo$g i j a]+$ ОЛ - pagal pagrindinio komponento etilenglikolio cheminès nomenklatūros priklausomybę).

Antifrizų trūkumas yra tas, kad jie šildomi plečiasi labiau negu vanduo, koroduoja metalus ir yra labai nuodingi.

Rūgštinis akumuliatorius - antrinis elementas, kuri galima ¡krauti prijungus prie kito elektros šaltinio. Rūgštinio akumuliatoriaus požymiai - jo elektrolitas yra skiesta sieros rūgštis, o plokštelès iš švino ir jo junginių. Kadangi vidinè jo varža labai maža, tai juo galima sukurti labai stiprią elektros srovę. Labiausiai paplitusi automobilio akumuliatorių baterija. Ji (12 V) sudaryta iš šešių nuosekliai sujungtu rūgštinių akumuliatorių.

Pagrindinè rūgštinio akumuliatoriaus sudedamoji dalis - sieros rūgštis. Akumuliatoriui išsikraunant, jos koncentracija mažèja. Jeigu i sieros rūgšti panardintos plokštelès būtų iš švino ir švino oksido, tai akumuliatoriui išsikraunant, jos pamažu virstų švino sulfidu. Didelio paviršiaus plokštelès leidžia pasiekti stiprią srovę.

Mūsų klimato sąlygomis akumuliatoriaus elektrolito tankis vasaros metu turètų būti 1,27-1,28 kg/1, o žiemą - 1,29-1,3 kg/1.

9.1 pav. pavaizduotas nešiojamas refraktometras.

Tada:

1. Prieš naudojant prietaisą būtina patikrinti, ar matavimo prizmè ir ją dengianti plokštele yra švarios.

2. Vanduo, naudojamas sureguliuojant prietaiso nulinę padetí, ir tiriamo skysčio mèginys turètų būti tos pačios temperatūros. Jei skysčių temperatūros iš esmès skiriasi, tuomet nulinis sureguliavimas turi būti atliekamas kas 30 min.

3. Prietaiso prizmè turi būti visiškai švari, nes net menkiausias nešvarumas gali iškreipti bandymo rodmenis.

4. Po bandymo prietaiso negalima plauti vandeniu, nes i prietaiso kamerą gali patekti vandens.

5. Priekinę matuoklio dali nukreipti šviesos šaltinio link, okuliaru 1 sureguliuoti vaizdo ryškumą, kad okuliaro regèjimo lauke būtu aiškiai matomos skalès. 
6. Prietaiso tikslumą galima išbandyti distiliuoto vandens mėginiu, t. y. matuokli reikia sureguliuoti nulinèje padètyje: atvožti prizmę dengiančią plokštelę 2, su pipete užlašinti ant prizmès vieną ar du lašus distiliuoto vandens, nuleisti plokštelę ir lengvai paspausti. Ant matuoklio korpuso esančia prietaiso sureguliavimo rankenėle 3 pareguliuoti, kad šviesaus ir tamsaus lauku skiriamoji linija sutaptu su vandens linija (WATERLINE). Baigus reguliuoti, pakelti plokštelę, vandenį nuo prizmès nusausinti komplekte esančia flaneline servetèle. Dabar prietaisas paruoštas atlikti bandymą su pageidaujamu skysčiu.

7. Pipete užlašinti lašeli bandomojo skysčio ant prizmès.

8. Nuleisti plokštelę ir lengvai ją paspausti, kad mėginio lašelis pasiskirstytu.

9. Okuliaru pasireguliuoti skalių vaizdo ryškuma.

10. Matuojamą vertę rodo atitinkamoje skalejje išryškèjusi skiriamoji linija tarp šviesaus ir tamsaus laukų.

11. Baigus matavima, bandomo skysčio likučius nuo prizmès ir dangtelio nuvalyti drègnu skudurèliu. Išgaravus drègmei, prietaisą idèti i jam skirtą dèklą.

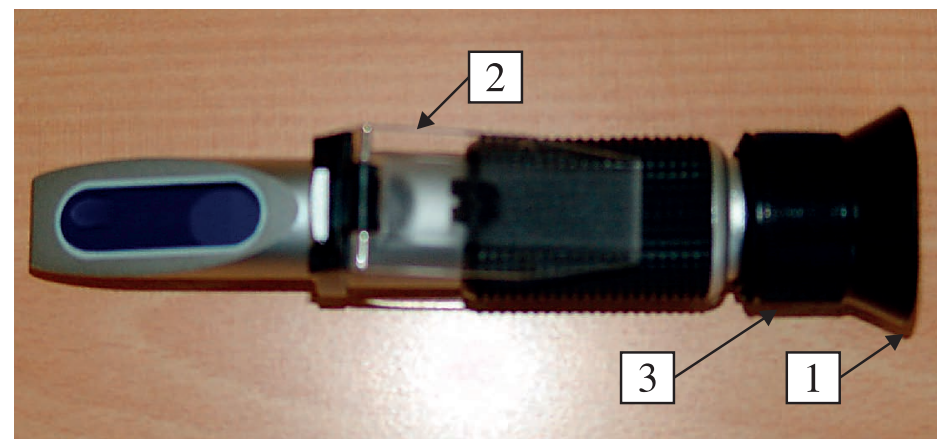

9.1 pav. Nešiojamas refraktometras:

1 - okuliaras, 2 - prizmę dengianti plokštelè, 3 - prietaiso sureguliavimo rankenèlè 


\section{Literatūra}

Baczewski, K.; Kałdoński, T. 2005. Paliwa do silników o zapłonie iskrowym. WKL, $244 \mathrm{~s}$.

Baczewski, K.; Kałdoński, T. 2008. Paliwa do silników o zapłonie samoczynnym. WKL, $224 \mathrm{~s}$.

Baltenas, R.; Sologubas, L.; Sologubas, R. 1998. Automobiliu degalai ir tepalai. Vilnius: TEV, $416 \mathrm{p}$.

Bureika, G.; Sokolovskij, E.; Pečeliūnas, R. 2008. Geležinkelio riedmenu tepimo medžiagos. Vilnius: Technika, $120 \mathrm{p}$.

Jakubkienè, V.; Brukštus, A. 2005. Organinès chemijos laboratoriniai darbai: Mokomoji knyga. Vilnius: Vilniaus universiteto leidykla, $90 \mathrm{p}$.

Jučas, P. 1992. Degalai ir tepalai: Chimotologija. Vilnius: Mokslas, 256 p.

Mang, T.; Dresel, W. 2007. Lubricants and lubrication: 2nd Edition. Wiley$\mathrm{VCH}, 850 \mathrm{p}$.

Matijošius, J.; Sokolovskij, E. 2009. Research into the quality of fuels and their biocomponents. Transport, 24 (3), 212-217 p.

Speight, J. G. 2008. Synthetic fuels handbook: Properties, process and performance. McGraw-Hill, $419 \mathrm{p}$.

Мартынюк, Н. П. и др. 1993. Автомобильные эксплуатационные материальы. М.: НПО „Поиск“, 275 с.

Синельников, А. Ф.; Балабанов, В. И. 2005. Автомобильные масла. Краткий справочник. М.: Издательство „За рулем“, 176 с.

Стуканов, В. А. 2003. Автомобильные эксплуатационные материальл. М.: Форум: Инфра-М, 208 с. 